\title{
Geochemistry of shales of the Qadir Member (Nayband Formation, Upper Triassic), East Central Iran (Tabas Block): implications for provenance and palaeogeography
}

\author{
Ehsan ZAMANIYAN ${ }^{1}$, Mohammad KHANEHBAD $^{1, *}$, Reza MOUSSAVI-HARAMI ${ }^{1}$ \\ and Asadollah MAHBOUBI ${ }^{1}$ \\ 1 Ferdowsi University of Mashhad, Department of Geology, Faculty of Science, Mashhad, Iran
}

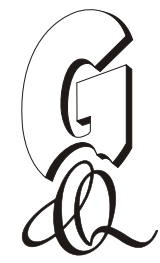

\begin{abstract}
Zamaniyan, E., Khanehbad, M., Moussavi-Harami, R., Mahboubi, A., 2019. Geochemistry of shales of the Qadir Member (Nayband Formation, Upper Triassic), East Central Iran (Tabas Block): implications for provenance and palaeogeography. Geological Quarterly, 63 (3): 603-618, doi: 10.7306/gq.1491
\end{abstract}

Associate editor: Tomasz Bajda

The Upper Triassic shale of the Qadir Member of the Nayband Formation, East Central Iran has been analysed geochemically to evaluate provenance and palaeogeography. The Qadir Member in the Parvadeh Coal Mine section is 450 metres thick, and includes sandstone, shale, coal, siltstone, and fossiliferous limestone. XRD analysis of shale samples from the Qadir Member largely indicated the presence of illite and chlorite, with small amounts of kaolinite and montmorillonite. On binary and triangular diagrams the data suggests an intermediate igneous source rock for these shales. Plotting the geochemical data on binary diagrams also indicates the tectonic setting of an active continental margin, perhaps reflecting the Early Cimmerian tectonic event with Neothetys subduction under the Iran Plate, and collision of the Iran Plate with Turan during the Late Triassic. The Chemical Index of Alteration (CIA) and Plagioclase Index of Alteration (PIA) values for shale from the Qadir Member of Nayband Formation vary from 74.04 to 80.54 (average 78.02) and 84.31 to 91.85 (average 87.81), respectively, indicating moderate to high chemical alteration in the source area and suggesting a semi-humid climate during deposition. The geochemical data and palaeogeographical models indicate that the Qadir Member shale was deposited on an active margin in a shoreline to transitional-marine setting.

Key words: Triassic, Nayband Formation, Tabas, provenance, geochemistry.

\section{INTRODUCTION}

In sedimentary geology, the term "provenance" is used to consider all the factors related to the production of sediments from source to sink. Many researchers have investigated how tectonics, and provenance relate to the composition of siliciclastic rocks (Dickinson and Suczek, 1979; Dickinson, 1985; Bhatia and Crook, 1986; Rieser et al., 2005; Fleming et al., 2016). Provenance analysis may be used to identify the source area(s) and assemblages of parent-rocks from initial erosion of the source rock to final burial of the sediments (Weltje, 2002; Weltje and von Eynatten, 2004; Khanehbad et al., 2012a). In general, the composition of siliciclastic rocks depends on the types of source rocks, palaeoclimate and topography (Jin et al., 2006; Armas et al., 2014; Mahavaraju, 2015). It is possible to interpret the provenance of siliciclastic rocks by using petrography and geochemical data via discriminant diagrams (Khanehbad et al., 2012b; Sabbagh Bajestani et al.,

\footnotetext{
* Corresponding author, e-mail: mkhanehbad@ferdowsi.um.ac.ir
} Received: October 14, 2018; accepted: July11, 2019; first published online: October 3, 2019
2018). Geochemical provenance studies are particularly applicable to shales, because of their homogeneity before deposition, their post-depositional impermeability and their higher abundance of trace elements relative to sandstones (Cullers, 2000; Hessler and Lower, 2006; DaPeng et al., 2012).

In this study, the provenance of siliciclastic rocks of the Qadir Member of the Nayband Formation in East Central Iran (Tabas Block) is interpreted and investigated through geochemical analysis. Geochemical data from shale is used to determine provenance (interpreting source rock, tectonic setting, palaeoweathering, and determining palaeogeography). This study allows for a better understanding of the palaeotectonic setting and palaeogeography of period in East Central Iran in the Triassic.

\section{GEOLOGY OF THE STUDY AREA}

During Permian times, the Central-East Iranian Microcontinent (CEIM) became detached from Gondwana and moved towards Eurasia. The ensuing collision caused the closure of the Palaeotethys Ocean and a series of events related to tectonic uplift, magmatism, and metamorphism traditionally termed the Early Cimmerian orogeny (Aghanabati, 2006; Wilmsen et al., 2009a). Following this orogeny, there was sea 


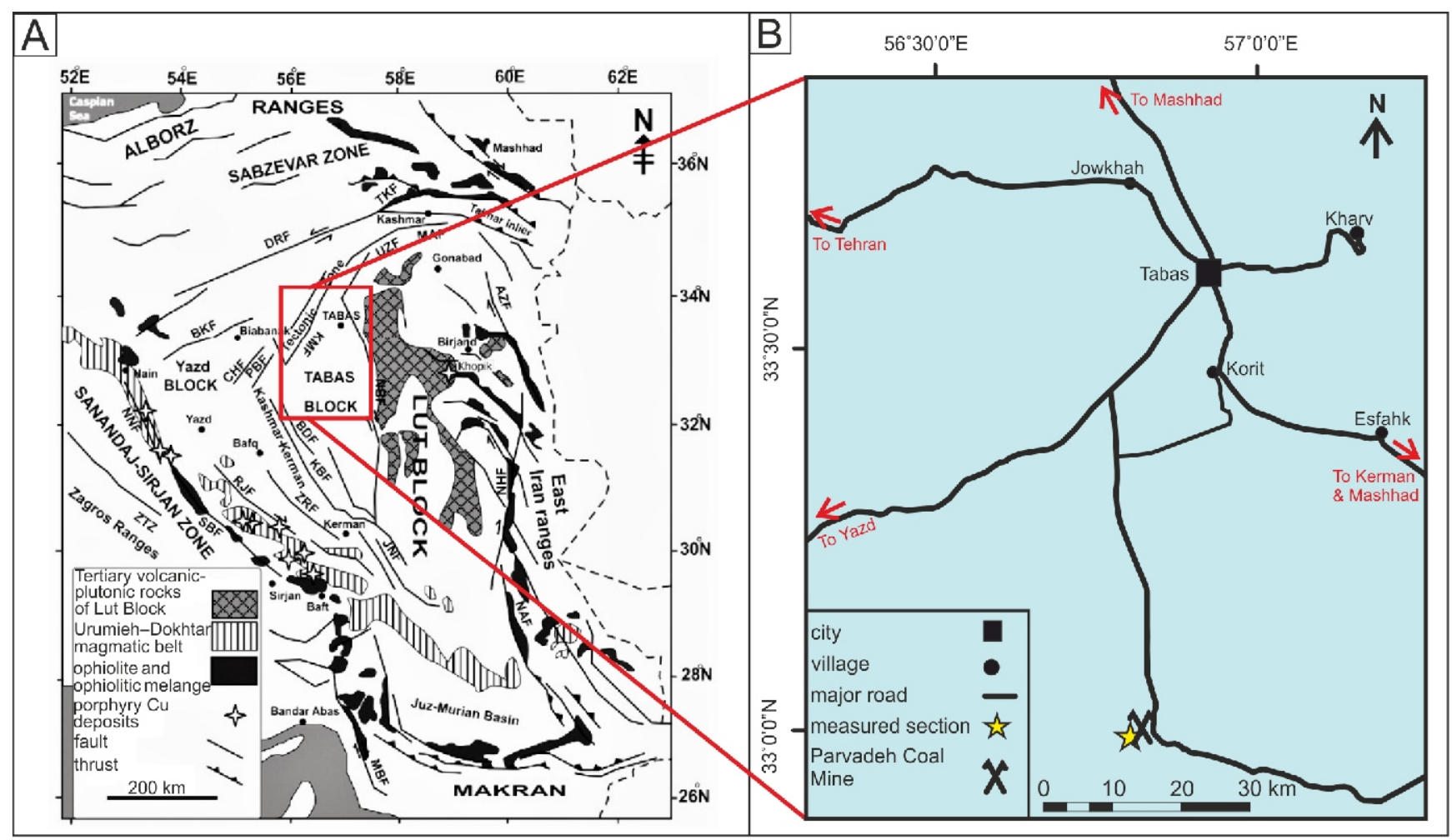

Fig. 1A - structural map of the Central-East Iranian Microcontinent and its crustal blocks (modified from Malekzadeh Shafaroudi et al., 2015); B - location of the section studied (yellow asterisk) to the south of Tabas

level rise and the Nayband Formation (Late Triassic), with a thickness of $3000 \mathrm{~m}$, was deposited in Central Iran's sedimentary structural zone. In the Late Triassic (Norian-Rhaetian), the Nayband Formation was distributed over a large area of central and eastern Iran (Seyed-Emami, 2003); its measured type section is placed south of the Nayband Mountain to the west of Nayband village (Aghanabati, 2006). As regards Iran's structural divisions (Aghanabati, 2006; Malekzadeh Shafaroudi et al., 2015), the study area is located in the central part of the Central-East Iranian Microcontinent (CEIM). The Tabas Block is an intra-continental depression and a part of the CEIM (Aghanabati, 2006) with a volatile geological history making it one of the most complex geological units in Iran.

The Qadir Member of the Nayband Formation in the

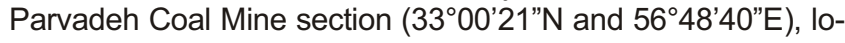
cated about $80 \mathrm{~km}$ south of Tabas, has been measured and studied in the Nayband sedimentary structural sub-block (subdivisions of the Tabas Block; Fig. 1). This formation is exposed extensively across the Tabas Block; one of the best exposures is located in the Parvadeh Coal Mine (PCM) zone, south of Tabas. The Nayband Formation on the southern flank of the central anticline of the PCM (termed the Sandwich anticline among local geologists) is $450 \mathrm{~m}$ thick (Figs. 2 and 3) and lithologically consists of shale and sandstone with intercalations of fossiliferous limestone and coal layers. Its lower boundary is unexposed in this section while the upper boundary is disconformable against the coarse-grained strata of the Ab-Haji
Formation (white sandstones and red-brown conglomerates Early Jurassic; Fig. 4).

\section{SAMPLES AND METHODS}

In studying the siliciclastic rocks of the Qadir Member in Parvadeh Coal Mine to the south of Tabas, following sampling and field studies, 10 samples of shale were selected to be analysed by XRF for determining major and trace elements and 3 samples of shale were selected for XRD analysis to identify the clay minerals. The shale samples were analysed by East Amethyst Analytical Geology Lab using an X-ray fluorescence device (Philips PW 1480 X-ray spectrometer). Ten shale exposure samples with minimal carbonate cement were cleaned and crushed to powder in agate mortars for major and trace element analysis. XRD analysis was also performed to identify clay minerals, by Geological Survey and Mineral Explorations, Northwest Branch (Tabriz center), using a Siemens D-5000 machine. To investigate microstructures and to determine the semi-quantitative composition of clay minerals in the Qadir Member deposits, a Scanning Electron Microscope (SEM, LEO 1450VP) was used, in the central laboratory of the Ferdowsi University of Mashhad, equipped with an Energy Dispersive X-ray (EDX) detector. Fresh surface samples were investigated using a scanning electron microscope (SEM). For this purpose, small fresh samples were broken and then were coated by Au-Pd sputter prior to examination. 


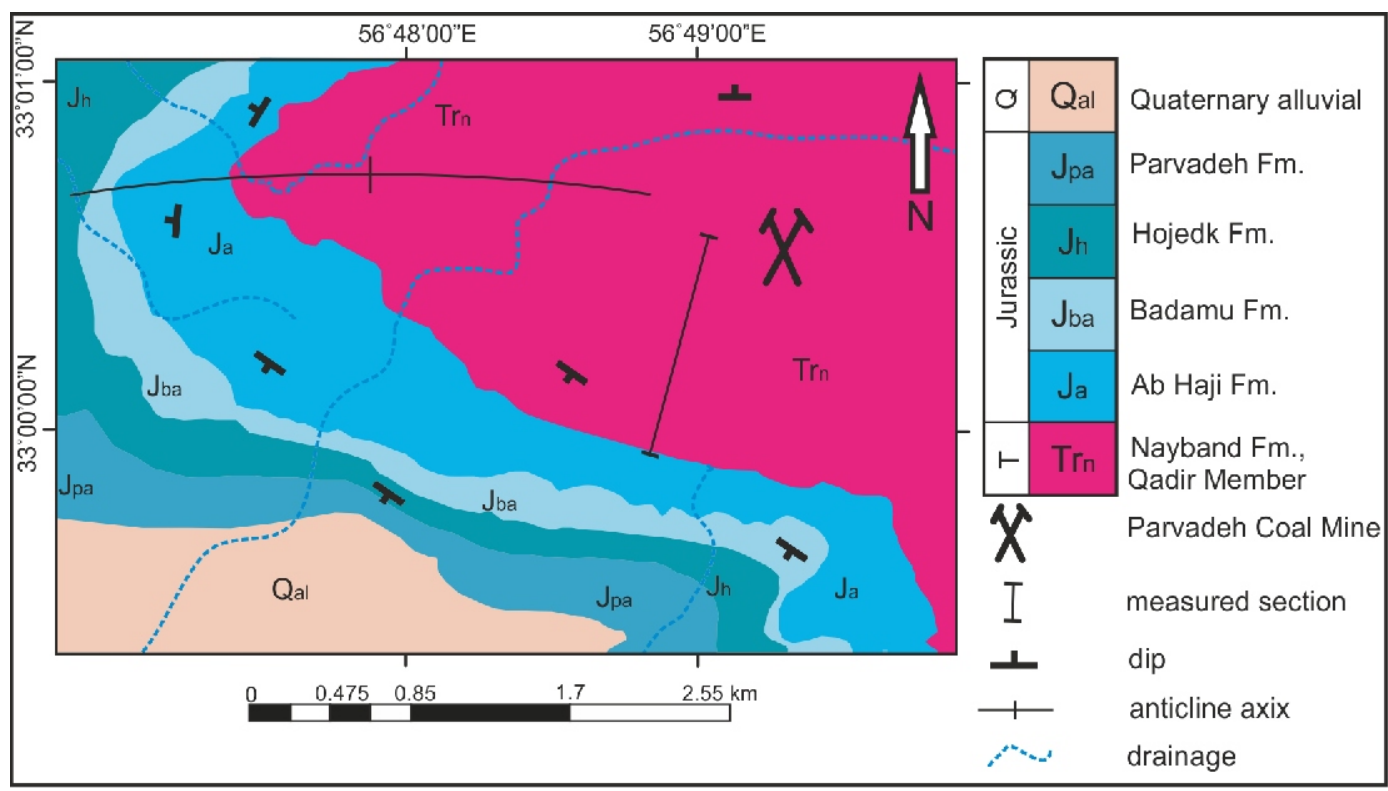

Fig. 2. Simplified geological map of the area

(modified after Moussavi-Harami and Ghaemi, 2006; Saidi et al., 2004)

\section{RESULTS}

\section{CLAY MINERALOGY}

XRD was used to identify clay minerals within the fine-grained deposits of the Qadir Member. Analysis of three shale samples show presence of illite and chlorite with small amounts of kaolinite and montmorillonite (Fig. 5). Illite and chlorite were also identified in SEM studies (Fig. 6).

\section{CHEMICAL COMPOSITION}

The data of major and trace element analyses of shale from the Qadir Member are outlined below and listed in Tables 1 and 2.

Results show that averages of oxides are $\mathrm{SiO}_{2} 59.97 \%$, $\mathrm{Al}_{2} \mathrm{O}_{3} 17.70 \%, \mathrm{Na}_{2} \mathrm{O} 1.69 \%, \mathrm{MgO} 2.35 \%, \mathrm{~K}_{2} \mathrm{O} 2.84 \%, \mathrm{TiO}_{2}$ $0.87 \%, \mathrm{MnO} 0.06 \%, \mathrm{CaO} 0.35 \%, \mathrm{P}_{2} \mathrm{O}_{5} 0.11 \%$ and $\mathrm{Fe}_{2} \mathrm{O}_{3}$ $6.47 \%$. The ratios of $\mathrm{SiO}_{2} / \mathrm{Al}_{2} \mathrm{O}_{3}$ (average 3.23\%), $\mathrm{K}_{2} \mathrm{O} / \mathrm{Na}_{2} \mathrm{O}$ (average $1.73 \%$ ), $\mathrm{K}_{2} \mathrm{O}+\mathrm{Na}_{2} \mathrm{O}$ (average $4.44 \%$ ), Chemical Index of Alteration (CIA: average 78.04), Plagioclase Index of Alteration (PIA: average 87.81) and Index of Compositional Variability (ICV: average 0.77 ) regarding the shales were calculated and are shown in Table 1.

The silica present may reflect the presence of quartz, chert, feldspar and clay minerals. Values of $\mathrm{Al}_{2} \mathrm{O}_{3}$ and $\mathrm{K}_{2} \mathrm{O}$ might be associated with the presence of K-feldspar (microcline), mica, and clay minerals. The $\mathrm{Na}_{2} \mathrm{O}$ is largely associated with $\mathrm{K}$-feldspar (albite). $\mathrm{TiO}_{2}$ is extensively associated with rutile, opaque minerals, and volcanic rocks. $\mathrm{Fe}_{2} \mathrm{O}_{3}$ may be associated with iron oxide, heavy minerals, and hematite cement. $\mathrm{MgO}$ and $\mathrm{CaO}$ could be associated with carbonate minerals (Khanehbad et al., 2012a), with $\mathrm{MgO}$ reflecting the presence of dolomite cement and $\mathrm{CaO}$ largely associated with calcite cement and skeletal fragments. The major elements of Qadir Member shale may be compared with the average chemical composition of the Upper Continental Crust (UCC; Taylor and McLennan, 1985; Fig. 7). Here, CaO is much lower than that of UCC while concentrations of most other major elements in the shales are generally similar to the mean composition of UCC. The low concentrations of $\mathrm{CaO}$ may either indicate a lack of original carbonate minerals or depletion in $\mathrm{Ca}$ during diagenesis (Salehi et al., 2014). $\mathrm{As} \mathrm{Al}_{2} \mathrm{O}_{3}$ remains generally unchangeable during alteration, metamorphism, and diagenesis, it can be applied as a factor for comparison with the other major elements (Getaneh, 2002; Akarish and El-Gohary, 2008). In the samples studied, the amount of $\mathrm{Al}_{2} \mathrm{O}_{3}$ was compared with other major oxides (Fig. 8). The $\mathrm{Fe}_{2} \mathrm{O}_{3}, \mathrm{~K}_{2} \mathrm{O}, \mathrm{MgO}$, $\mathrm{Na}_{2} \mathrm{O}$ and $\mathrm{TiO}_{2}$ contents show a positive relationship with $\mathrm{Al}_{2} \mathrm{O}_{3}$. This reflects the presence of clay minerals, especially aluminosilicate (Pettijohn et al., 1987; Das et al., 2006; Khanehbad et al., 2012b). The positive relationship of $\mathrm{K}_{2} \mathrm{O}$ with $\mathrm{Al}_{2} \mathrm{O}_{3}$ suggests the presence of potassium-rich minerals (Jin et al., 2006). By contrast, values of $\mathrm{CaO}, \mathrm{SiO}_{2}, \mathrm{MnO}$ and $\mathrm{P}_{2} \mathrm{O}_{5}$ show a negative relationship with $\mathrm{Al}_{2} \mathrm{O}_{3}$. The negative correlation of $\mathrm{SiO}_{2}$ with most major elements (for example with $\mathrm{Al}_{2} \mathrm{O}_{3}$ ) is due to most silica being sequestered in quartz, as indicated by Osman (1996). This could be because of the presence of more quartz phases and a high textural and compositional maturity of the samples studied (Bayat-Goll and Hosseini Barzi, 2011; Salehi et al., 2014). The reverse relationship with $\mathrm{CaO}$ may be related to a calcite diagenetic cement and secondary alteration (Das et al., 2006). The $\mathrm{K}_{2} \mathrm{O} / \mathrm{Na}_{2} \mathrm{O}$ binary diagrams against $\mathrm{SiO}_{2} / \mathrm{Al}_{2} \mathrm{O}_{3}$ (Wronkiewicz and Condie, 1987) for the shale in the Qadir Member suggest that it lies within the range of Phanerozoic shale composition (Fig. 9). Trace elements determined in this study reveals a dominance of $\mathrm{Rb}, \mathrm{Ba}, \mathrm{Sr}, \mathrm{Th}, \mathrm{Cr}, \mathrm{Y}, \mathrm{Zr}, \mathrm{Nb}, \mathrm{V}, \mathrm{Co}, \mathrm{Cu}$ and $\mathrm{Ni}$ (Table 2). In Figure 10, Ni, V, Rb and $\mathrm{Y}$ are positively correlated with $\mathrm{Al}_{2} \mathrm{O}_{3}$. The results also show that trace element averages (ppm) are $\mathrm{Rb} 174, \mathrm{Ba} 68, \mathrm{Sr} 165.2, \mathrm{Th} 13, \mathrm{Cr} 86.1, \mathrm{Y} 68.5$, Zr 288.4, Nb 17.2, V 112.1, Co 16.3, Cu 87.7, Ni 72.6.

\section{DISCUSSION}

\section{SOURCE ROCK}

Many researchers have studied the relationship between the chemical composition of siliciclastic rocks and the source area (Khanehbad et al., 2012b; Salehi et al., 2014; Valiani and Rezaee, 2014; Zaid, 2015). The geochemistry of shale is more applicable than the petrology of sandstone for interpretation of the source rocks (Cullers, 2000). The ratio of $\mathrm{Al}_{2} \mathrm{O}_{3}$ to $\mathrm{TiO}_{2}$ in 


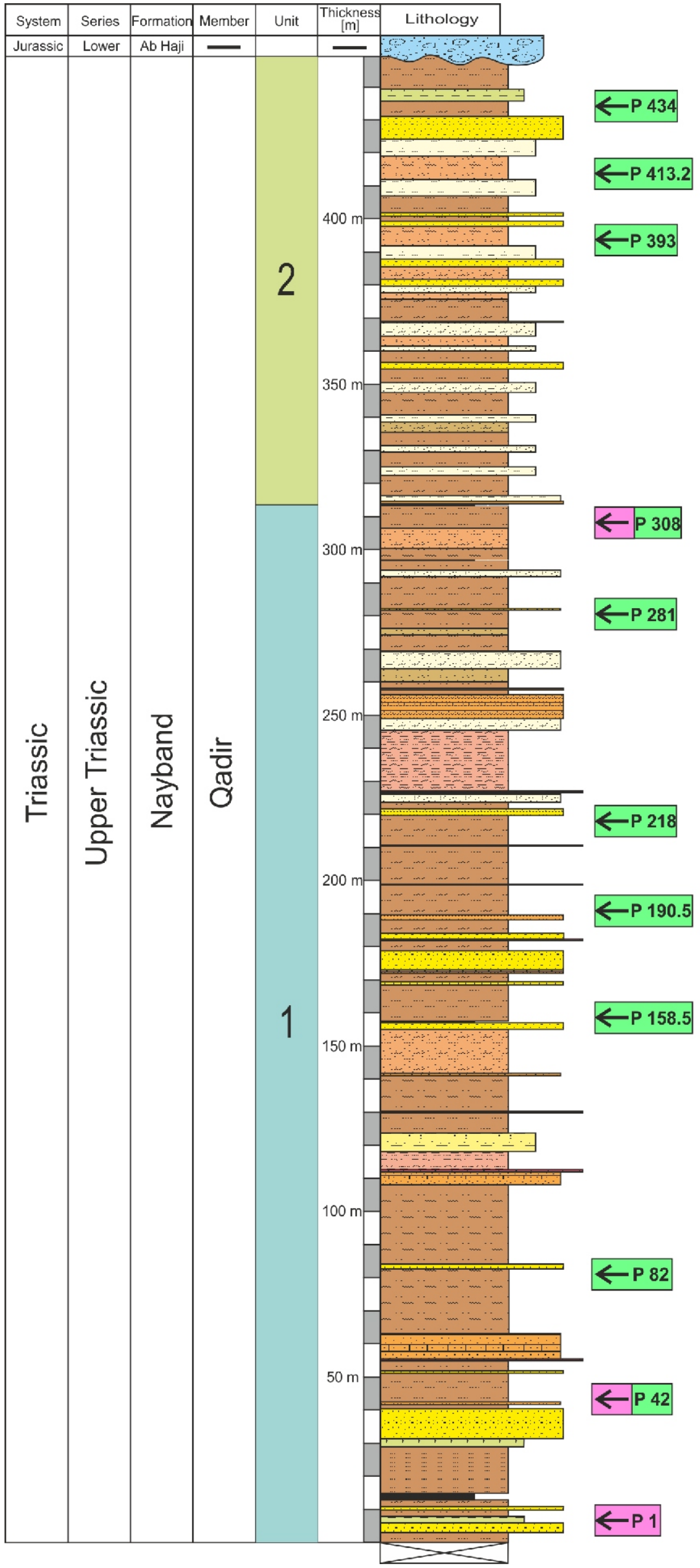

XRF Analysis
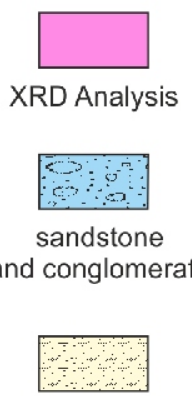

shale and sandstone
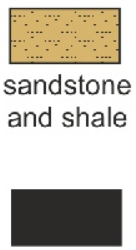

coal

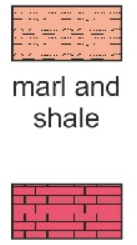

fossiliferous limestone

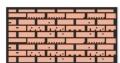

fossiliferous sandy limestone

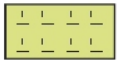

silty shale

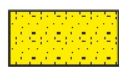

sandstone

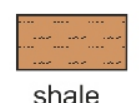

shale

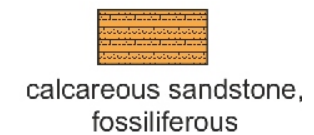

fossiliferous

Fig. 3. Lithostratigraphic column of the Qadir Member of the Nayband Formation in the area studied, location of samples collected for XRF and XRD are shown 


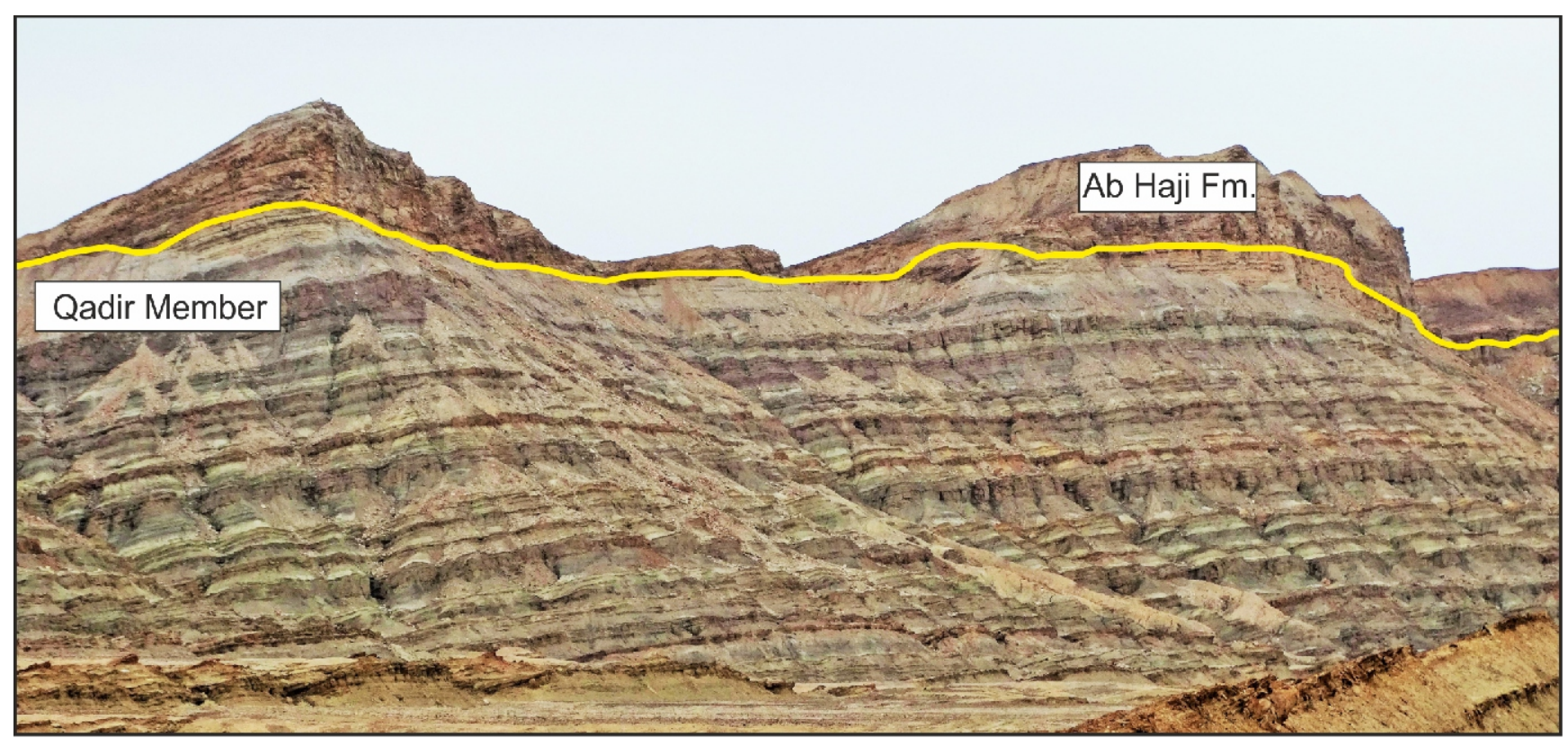

Fig. 4. Field photograph of the Qadir Member section of the Nayband Formation (Upper Triassic) in the Parvadeh Coal Mine area

Major element (oxide wt.\%) composition of shale from the Qadir Member of Nayband Formation

\begin{tabular}{|c|c|c|c|c|c|c|c|c|c|c|c|c|}
\hline & \multicolumn{12}{|c|}{ Sample no. } \\
\hline & P 42 & P 82 & P 158.5 & P 190.5 & P 218 & P 281 & P 308 & P 393 & P 413.2 & P 434 & Average & UCC \\
\hline $\mathrm{SiO}_{2}$ & 61.50 & 57.05 & 56.55 & 55.56 & 60.74 & 56.01 & 57.02 & 67.01 & 65.77 & 62.53 & 59.97 & 66 \\
\hline $\mathrm{Al}_{2} \mathrm{O}_{3}$ & 18.00 & 17.85 & 17.13 & 21.38 & 16.95 & 19.93 & 18.74 & 15.29 & 15.68 & 16.10 & 17.7 & 15.2 \\
\hline $\mathrm{Na}_{2} \mathrm{O}$ & 2.58 & 1.86 & 1.98 & 1.44 & 1.50 & 1.97 & 1.43 & 1.45 & 1.33 & 1.39 & 1.69 & 3.9 \\
\hline $\mathrm{MgO}$ & 1.17 & 3.26 & 3.44 & 2.41 & 2.80 & 2.50 & 2.77 & 1.87 & 1.60 & 1.76 & 2.35 & 2.2 \\
\hline $\mathrm{K}_{2} \mathrm{O}$ & 2.83 & 2.77 & 2.96 & 3.89 & 2.70 & 3.56 & 3.36 & 2.00 & 2.16 & 2.26 & 2.84 & 3.4 \\
\hline $\mathrm{TiO}_{2}$ & 1.02 & 0.81 & 0.90 & 0.91 & 0.85 & 0.92 & 0.98 & 0.75 & 0.87 & 0.76 & 0.87 & 0.5 \\
\hline $\mathrm{CaO}$ & 0.10 & 0.16 & 0.47 & 0.11 & 1.15 & 0.01 & 0.18 & 0.86 & 0.30 & 0.24 & 0.35 & 4.2 \\
\hline $\mathrm{Fe}_{2} \mathrm{O}_{3}$ & 4.36 & 6.08 & 7.16 & 7.14 & 6.29 & 5.10 & 6.70 & 5.37 & 7.34 & 9.19 & 6.47 & 5.04 \\
\hline $\mathrm{MnO}$ & 0.04 & 0.07 & 0.07 & 0.05 & 0.07 & 0.03 & 0.08 & 0.07 & 0.09 & 0.10 & 0.06 & - \\
\hline $\mathrm{P}_{2} \mathrm{O}_{5}$ & 0.11 & 0.13 & 0.11 & 0.08 & 0.12 & 0.07 & 0.14 & 0.14 & 0.12 & 0.12 & 0.11 & - \\
\hline $\mathrm{SO}_{3}$ & 0.14 & 0.06 & 0.22 & 0.02 & 0.00 & 0.12 & 0.04 & 0.06 & 0.00 & 0.03 & 0.6 & - \\
\hline LOI & 6.50 & 9.11 & 8.03 & 6.66 & 6.41 & 8.79 & 8.22 & 4.79 & 4.52 & 5.25 & 6.82 & - \\
\hline PIA & 84.98 & 88.18 & 85.25 & 91.85 & 84.31 & 89.2 & 90.52 & 85.19 & 89.24 & 89.46 & 87.81 & - \\
\hline $\mathrm{CIA}$ & 75.56 & 78.84 & 74.02 & 79.71 & 76 & 78.24 & 79.03 & 78.01 & 80.53 & 80.54 & 78.04 & - \\
\hline ICV & 0.61 & 0.79 & 0.93 & 0.7 & 0.85 & 0.65 & 0.77 & 0.75 & 0.81 & 0.92 & 0.77 & - \\
\hline
\end{tabular}

LOI - loss of ignition; PIA - Plagioclase Index Alteration; CIA - Chemical Index of Alteration; ICV - Index of Compositional Variability 

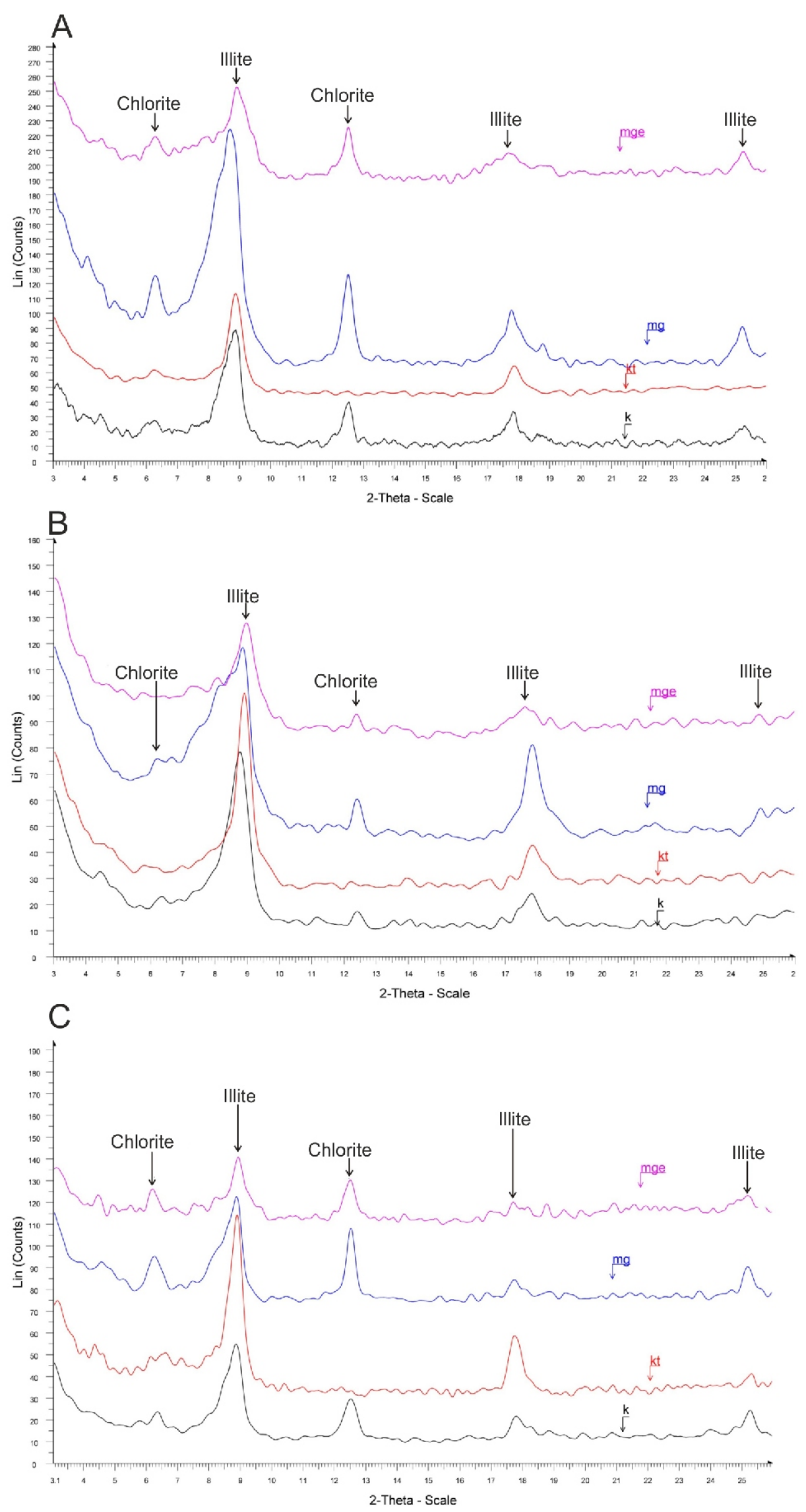

Fig. 5. X-ray diffraction pattern of samples of Qadir Member shale

A - sample P 1; B - sample P 42; C - P 308 ; $k$ - the graph was taken at $550^{\circ} \mathrm{C}$ by potassium chloride; $k$ - peak distinction of kaolinite from chlorite; $\mathrm{mg}$ and $\mathrm{mge}-$ peak distinction of chlorite from montmorillonite 

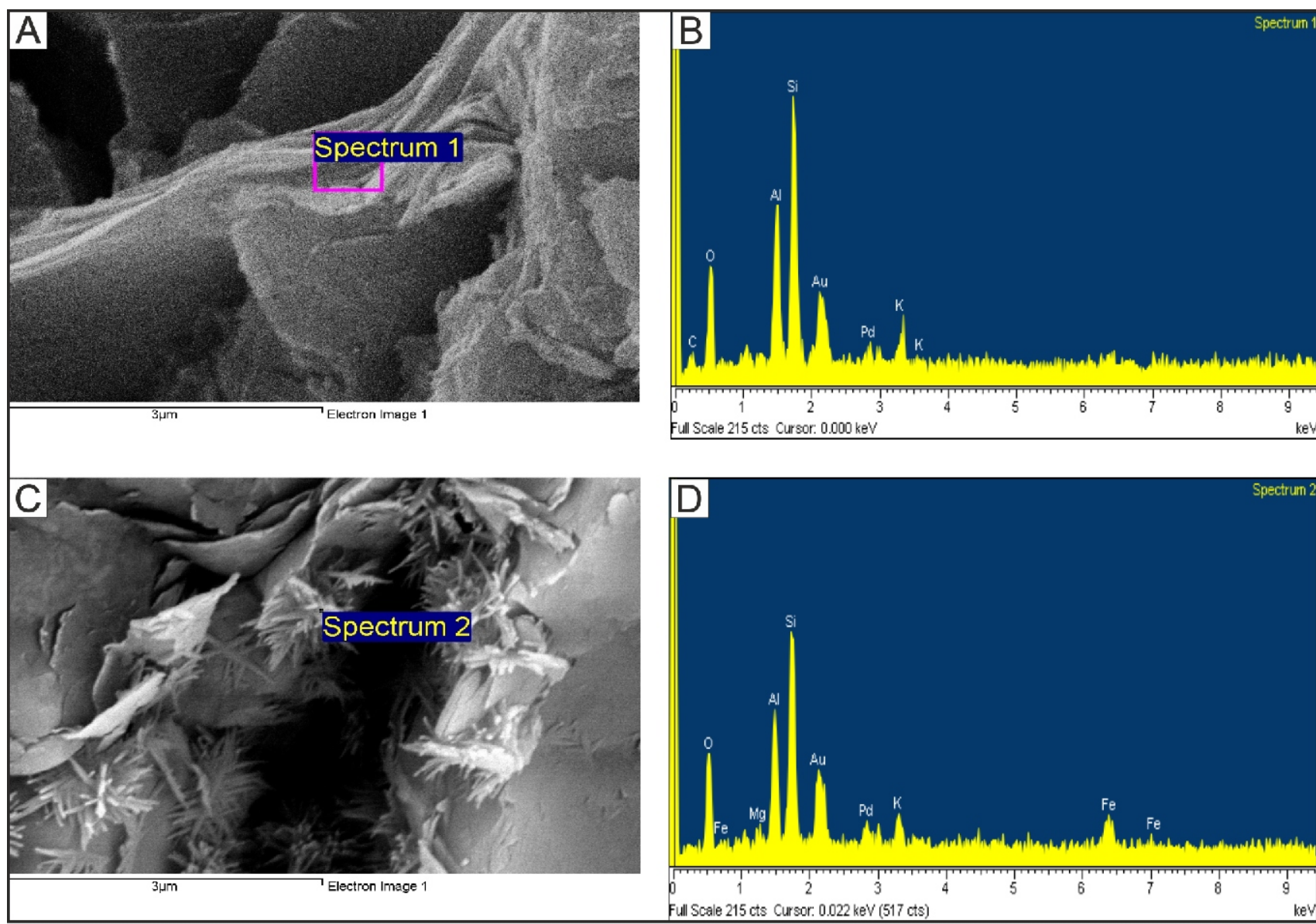

Fig. 6. SEM pictures of Qadir Member shale

A - illite with sheet structure; B - EDX analysis of A; C - chlorite (asterisk) with needle structure; D - EDX analysis of C

Trace element (ppm) composition of shale from the Qadir Member

\begin{tabular}{|l|r|r|r|r|r|r|r|r|r|r|r|}
\hline & \multicolumn{10}{|c|}{ Sample no. } \\
\cline { 2 - 15 } & $\mathrm{P} 42$ & $\mathrm{P} 82$ & $\mathrm{P} 158.5$ & $\mathrm{P} 190.5$ & $\mathrm{P} \mathrm{218}$ & $\mathrm{P} 281$ & $\mathrm{P} 308$ & $\mathrm{P} \mathrm{393}$ & $\mathrm{P} 413.2$ & $\mathrm{P} 434$ & Average \\
\hline $\mathrm{Rb}$ & 180 & 157 & 186 & 259 & 153 & 245 & 200 & 117 & 123 & 120 & 174 \\
\hline $\mathrm{Ba}$ & 4 & 95 & 62 & 77 & 98 & 63 & 47 & 88 & 49 & 97 & 68 \\
\hline $\mathrm{Sr}$ & 216 & 139 & 141 & 139 & 148 & 261 & 159 & 144 & 168 & 137 & 165.2 \\
\hline $\mathrm{Th}$ & 11 & 11 & 14 & 16 & 11 & 13 & 21 & 13 & 9 & 11 & 13 \\
\hline $\mathrm{Cr}$ & 95 & 85 & 93 & 107 & 84 & 103 & 88 & 65 & 75 & 66 & 86.1 \\
\hline $\mathrm{Y}$ & 77 & 67 & 73 & 78 & 64 & 83 & 79 & 49 & 67 & 48 & 68.5 \\
\hline $\mathrm{Zr}$ & 342 & 289 & 269 & 251 & 297 & 259 & 254 & 295 & 323 & 305 & 288.4 \\
\hline $\mathrm{Nb}$ & 9 & 9 & 17 & 17 & 13 & 15 & 18 & 12 & 46 & 16 & 17.2 \\
\hline $\mathrm{V}$ & 113 & 110 & 119 & 146 & 102 & 133 & 128 & 83 & 98 & 89 & 112.1 \\
\hline $\mathrm{Co}$ & 13 & 17 & 18 & 19 & 14 & 13 & 19 & 12 & 17 & 21 & 16.3 \\
\hline $\mathrm{Cu}$ & 114 & $\mathrm{~N}$ & 99 & 74 & 54 & 107 & 89 & 150 & 82 & 108 & 87.7 \\
\hline $\mathrm{Ni}$ & 66 & 80 & 75 & 93 & 70 & 77 & 94 & 58 & 46 & 67 & 72.6 \\
\hline
\end{tabular}




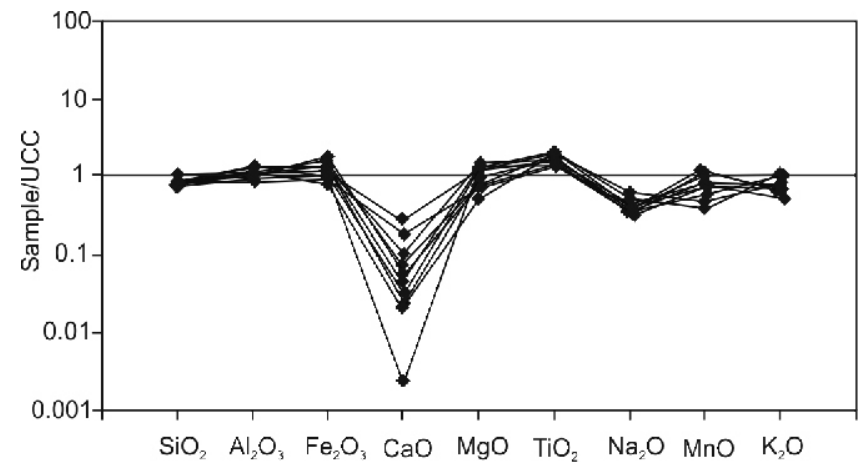

Fig. 7. Normalization of major oxides of Qadir Member shale in comparison with Upper Continental Crust (UCC; Taylor and McLennan, 1985)
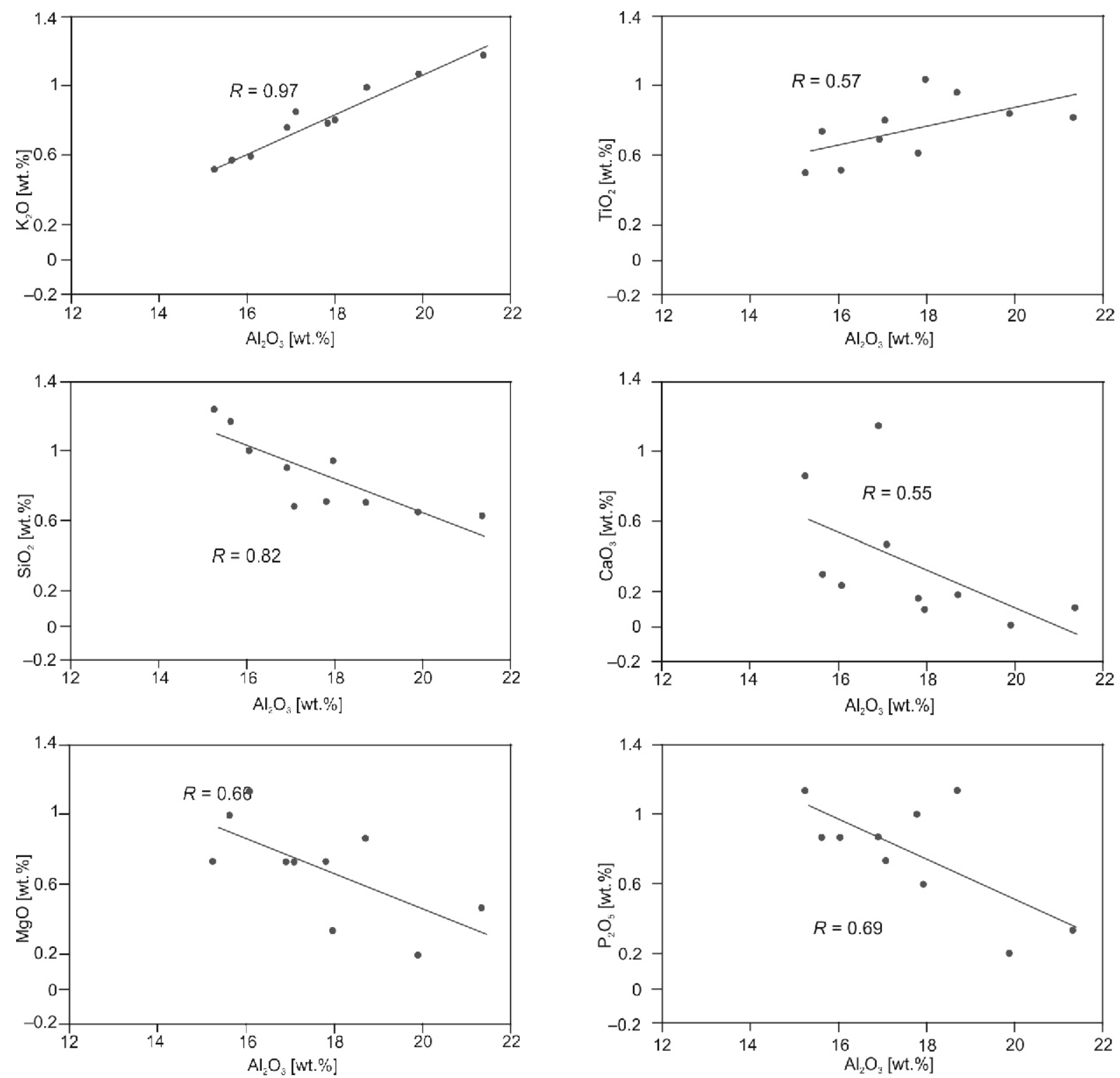

Fig. 8. Changes of major oxides versus $\mathrm{Al}_{2} \mathrm{O}_{3}$ in the Qadir Member shales 


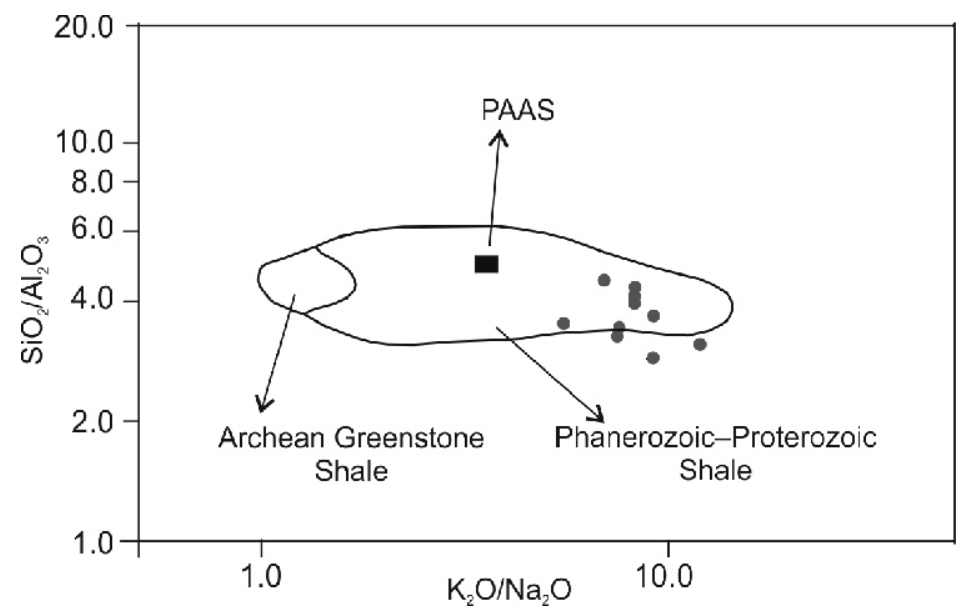

Fig. 9. $\mathrm{K}_{2} \mathrm{O} / \mathrm{Na}_{2} \mathrm{O}$ versus $\mathrm{SiO}_{2} / \mathrm{Al}_{2} \mathrm{O}_{3}$ plot for shale of the Qadir Member

Fields for the Archean Greenstone Shale and Phanerozoic shale after Wronkiewicz and Condie (1987)
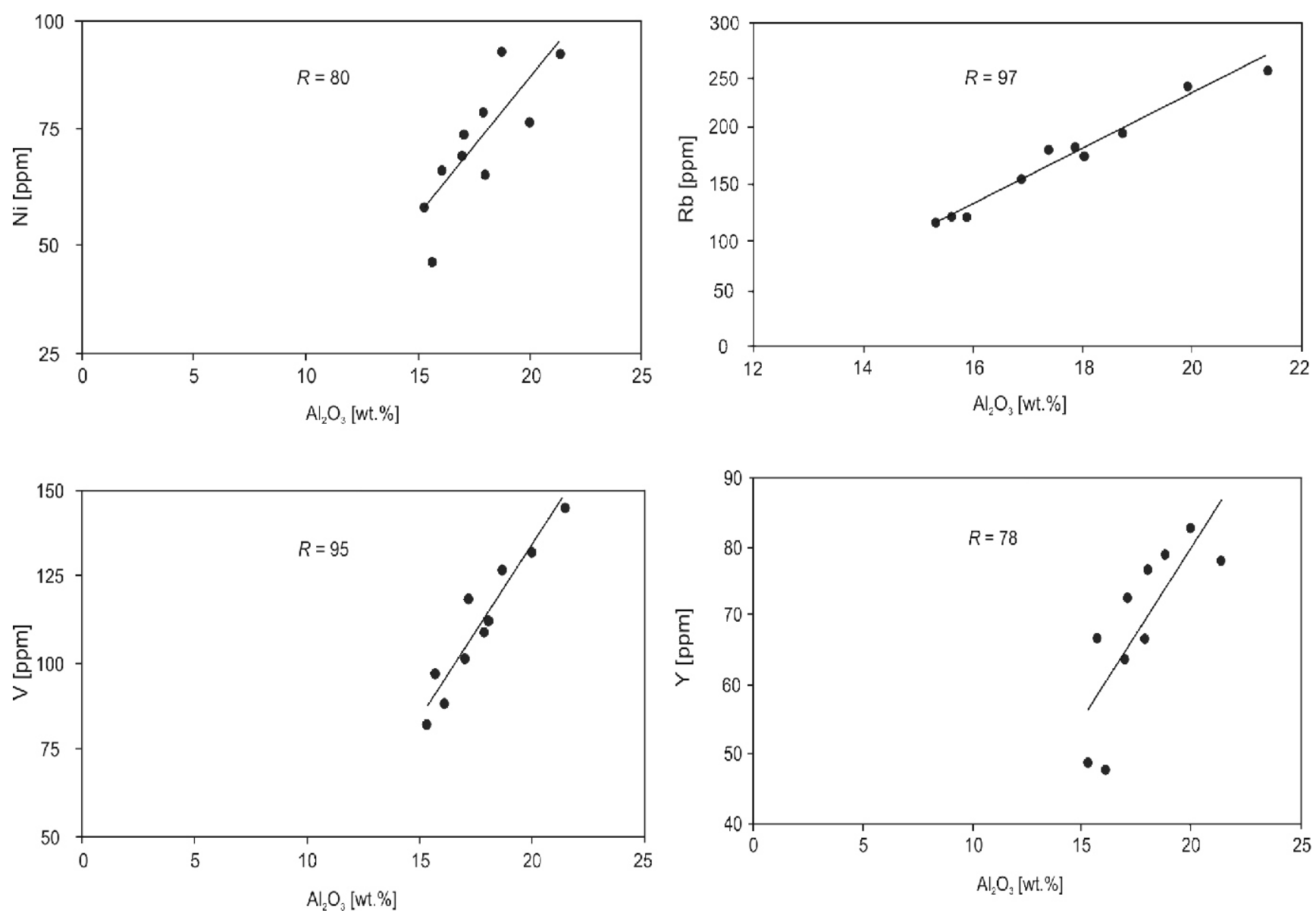

Fig. 10. Discrimination plots $\mathrm{Al}_{2} \mathrm{O}_{3}$ and trace elements (Ni, V, Rb, and $\mathrm{Y}$ ) for shale of Qadir Member 

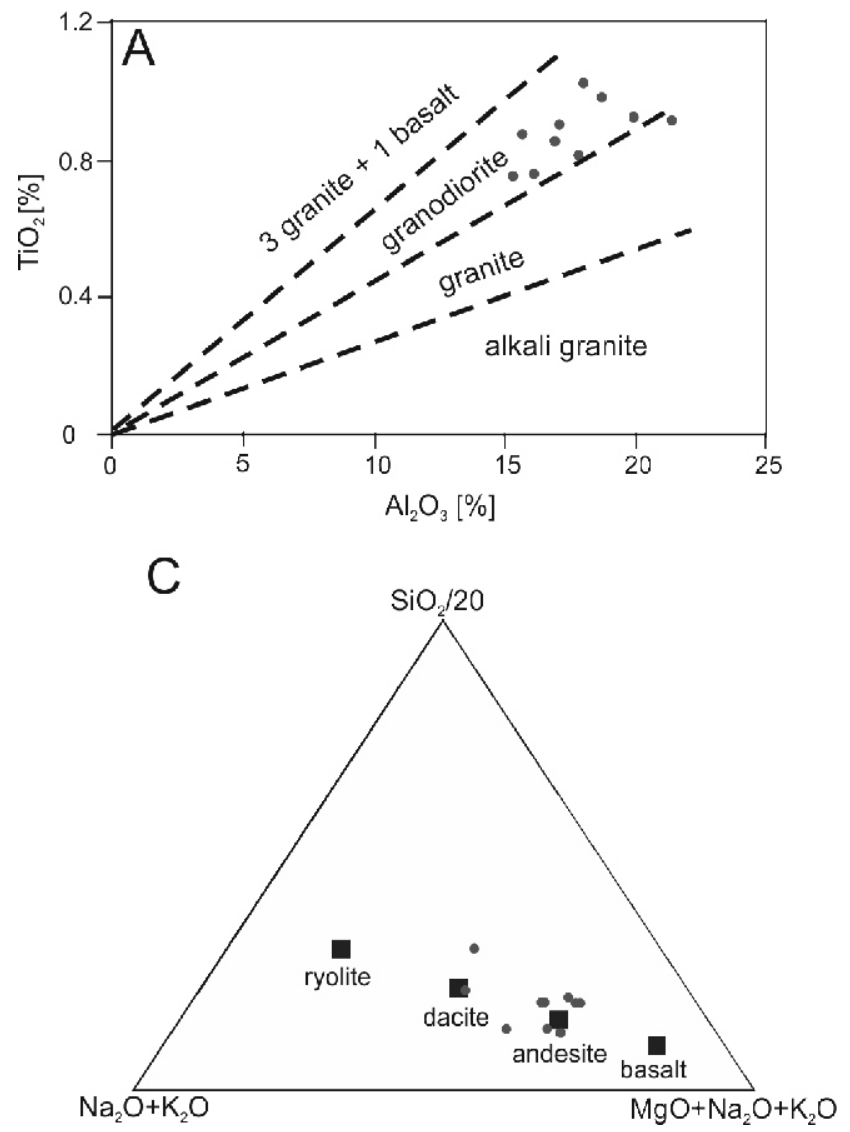
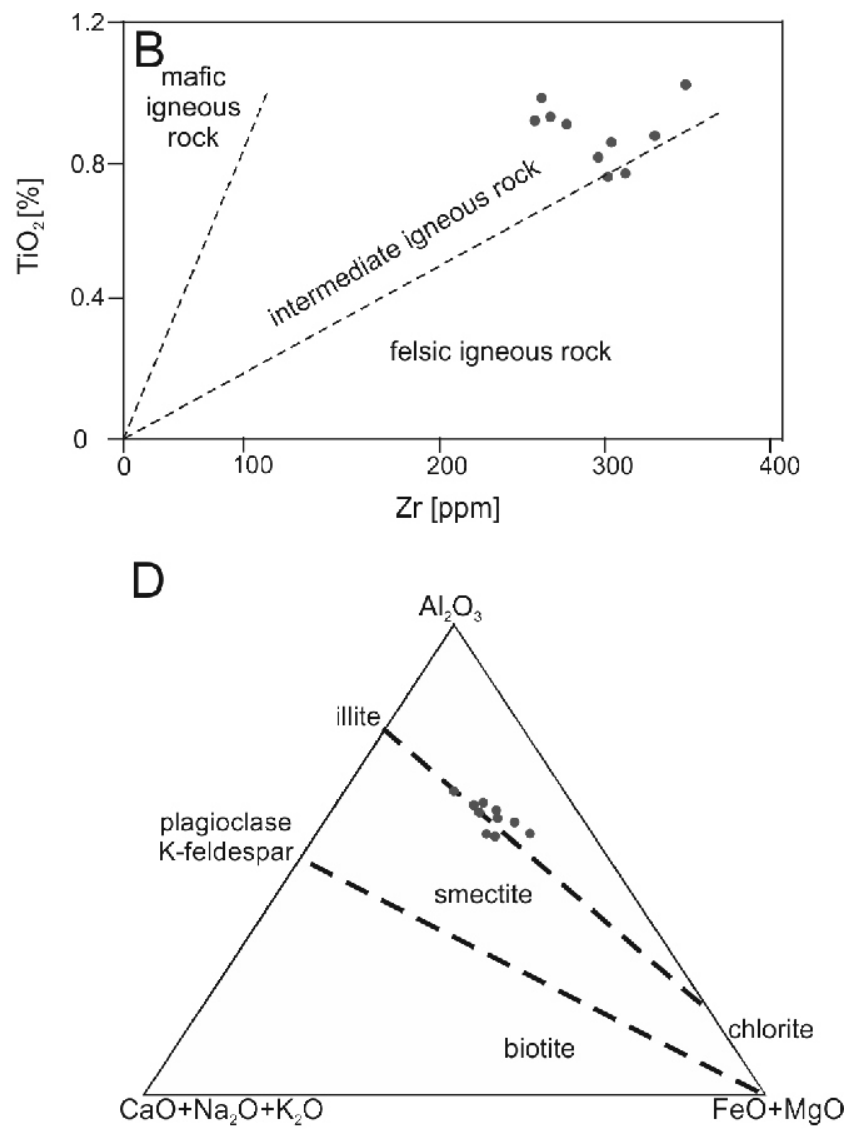

Fig. 11A - ratio of $\mathrm{Al}_{2} \mathrm{O}_{3}$ major oxides compared with $\mathrm{TiO}_{2}$ (Schieber, 1992); $\mathrm{B}-\mathrm{TiO}_{2}$ (wt.\%) versus $\mathrm{Zr}$ (ppm) bivariate diagram (Paikaray et al., 2008); $\mathrm{C}-\mathrm{SiO}_{2} / 20-\mathrm{Na}_{2} \mathrm{O}+\mathrm{K}_{2} \mathrm{O}-\mathrm{MgO}+\mathrm{TiO}_{2}+\mathrm{FeO}$ ternary diagram (Hayeshi et al., 1997); $\mathrm{D}-$ plotting the data on the $\mathrm{FeO}+\mathrm{MgO}-\mathrm{CaO}+\mathrm{Na}_{2} \mathrm{O}+\mathrm{K}_{2} \mathrm{O}-\mathrm{Al}_{2} \mathrm{O}_{3}$ ternary diagrams (Hayeshi et al., 1997)
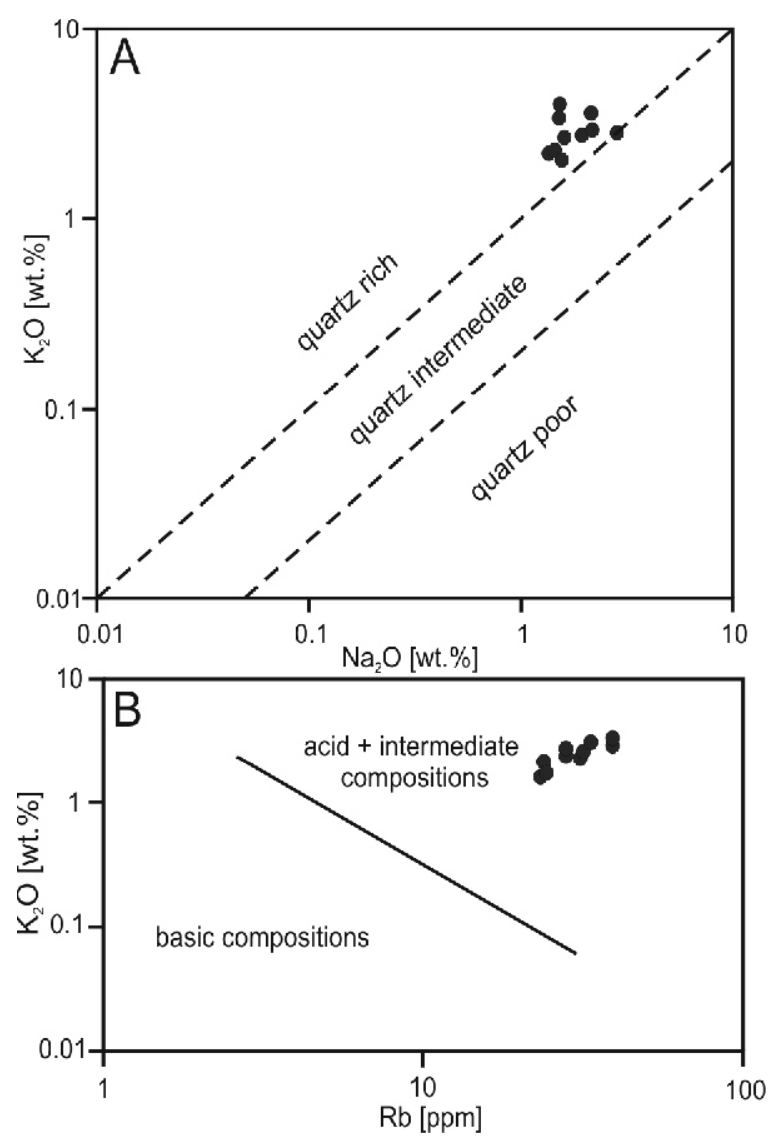

shales is a very good indicator of shale source rock compared to the other major elements (Paikaray et al., 2008). Plotting data regarding $\mathrm{Al}_{2} \mathrm{O}_{3}$ versus $\mathrm{TiO}_{2}$ on the Scheiber (1992) diagram shows that these shales are situated in the range of granodiorite igneous source rock (Fig. 11A). Using the Paikaray et al. (2008) diagram, of $\mathrm{Zr}$ against $\mathrm{TiO}_{2}$, our data show that the shale of the Qadir Member plots as an intermediate igneous source rock (Fig. 11B). Plotting the data on the Hayeshi et al. (1997) ternary diagram, these shales are mainly located in the range of andesite to dacite, which suggests an intermediate igneous source rock (Fig. 11C). In the Hayeshi et al. (1997) diagrams, of $(\mathrm{FeO}+\mathrm{MgO}),\left(\mathrm{CaO}+\mathrm{Na}_{2} \mathrm{O}+\mathrm{K}_{2} \mathrm{O}\right)$, and $\left(\mathrm{Al}_{2} \mathrm{O}_{3}\right)$, the dispersion of the shale data from the Qadir Member is in the range of illite and chlorite (Fig. 11D). The inference of illite and chlorite from the major elements oxide data also corresponds with the data obtained from XRD analysis (Fig. 5). On the $\mathrm{Na}_{2} \mathrm{O}-\mathrm{K}_{2} \mathrm{O}$ diagram (Fig. 12A), the Qadir Member shale data plots in the quartz-rich field. Floyd and Leveridge (1987) plotted $\mathrm{K}_{2} \mathrm{O}$ versus $\mathrm{Rb}$ to distinguish sediments derived from acidic to intermediate rocks from those derived from basic rocks. Most of the shale of the Qadir Member studied lies in the field of acid and intermediate compositions (Fig. 12B).

Elevated values of $\mathrm{Cr}>150 \mathrm{ppm}$ and $\mathrm{Ni}>100$ ppm are suggestive of ultramafic rocks in the source region (Garver et al., 1996). By comparison, $\mathrm{Cr}$ in these shales varies from 65 to

Fig. 12A - analysis of shales according to the richness of quartz of the Qadir Member (after Crook, 1974); B - $\mathrm{K}_{2} \mathrm{O}$ versus $\mathrm{Rb}$ diagram of the shale of the Qadir Member (fields after Floyd and Leveridge, 1987) 

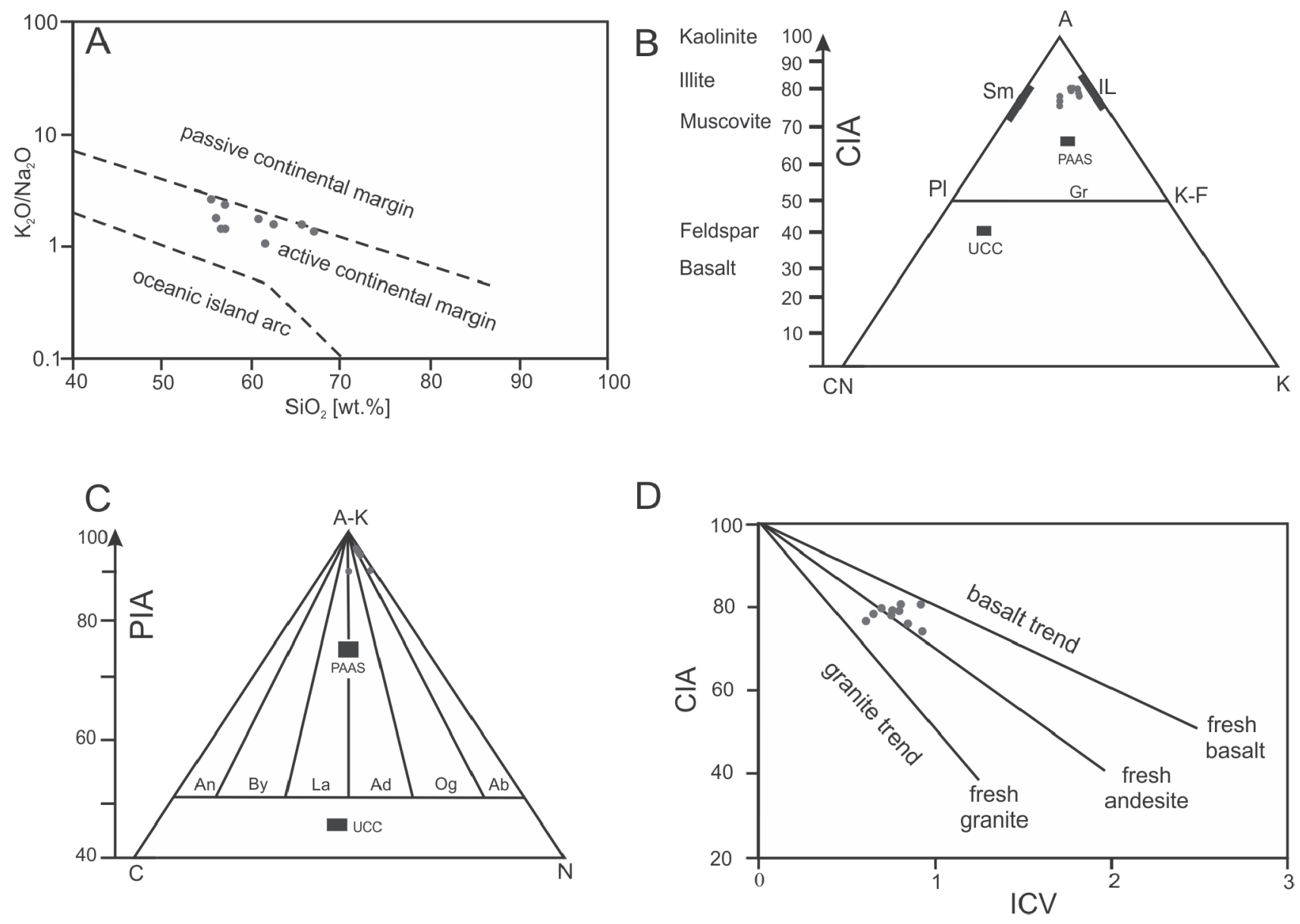

Fig. 13A- $\mathrm{SiO}_{2}$ versus $\mathrm{K}_{2} \mathrm{O} / \mathrm{Na}_{2} \mathrm{O}$ discrimination plot of Roser and $\mathrm{Korsch}$ (1988); B - A-CN-K ternary diagram for shales of the Qadir member (Paikaray et al., 2008; $\mathrm{A}-\mathrm{Al}_{2} \mathrm{O}_{3}, \mathrm{CN}-\mathrm{CaO}+\mathrm{Na}_{2} \mathrm{O}, \mathrm{K}-\mathrm{K}_{2} \mathrm{O}$ ); C $-\mathrm{A}-\mathrm{K}-\mathrm{C}-\mathrm{N}$ ternary diagram of molecular proportions of A-K $\mathrm{Al}_{2} \mathrm{O}_{3}-\mathrm{K}_{2} \mathrm{O}, \mathrm{C}-\mathrm{CaO}, \mathrm{N}-\mathrm{Na}_{2} \mathrm{O}$ (An - anorthite, $\mathrm{By}$ - bytownite, La - labradorite, Ad - andesine, Og-oligoclase, Ab - albite; Fedo et al., 1995); D - ICV against ICA dual diagram (Cox et al., 1995; Potter et al., 2005) suggesting an intermediate igneous rock source

$107 \mathrm{ppm}$ (average $86.1 \mathrm{ppm}$ ) and Ni concentration varies from 46 to $94 \mathrm{ppm}$ (average $72.6 \mathrm{ppm}$ ). This makes the presence of significant mafic and ultramafic rocks in the source area most unlikely. Also, these shales show enriched values of $\mathrm{Zr}$, $\mathrm{Sr}$ and $\mathrm{Rb}$ and depletion in $\mathrm{Nb}, \mathrm{Y}, \mathrm{Cr}$ and $\mathrm{Ni}$. Felsic rocks commonly have lower $Y$ and $\mathrm{Nb}$ than mafic rocks (Humphreys et al., 1995). This suggests that almost all of these samples were derived from plutonic and intermediate igneous rocks. In general, based on the available data, an intermediate igneous source rock is suggested as a source for the shale of the Qadir Member.

\section{TECTONIC SETTING}

The chemical composition of sedimentary rocks can give clues not only about reworking, recycling and weathering conditions, but also on the tectonic setting of their depositional basin. For this purpose, geochemical discrimination diagrams have been developed and used (e.g., Bhatia 1983; Bhatia and Crook 1986; Roser and Korsch, 1986, 1988; Verma and Armstrong-Altrin, 2013), including in Iran (Moosavirad et al., 2011; Khanehbad et al., 2012b; Jafarzadeh et al., 2014; Salehi et al., 2014, 2018).

Plotting $\mathrm{SiO}_{2}$ against $\mathrm{K}_{2} \mathrm{O} / \mathrm{Na}_{2} \mathrm{O}$ is commonly used to identify the tectonic setting of shales (Bhatia, 1983; Roser and Korsch, 1988). According to the binary diagrams of Roser and Korsch (1988), the samples of shale in Qadir Member have been largely deposited on an active continental margin
(Fig. 13A). This inferred tectonic activity may correspond to the Early Cimmerian Orogeny at the boundary of Middle and Late Triassic time (the boundary between Shotori Formation and the Nayband Formation), concurrent with the orogenic phase of the Early Cimmerian in Central-East Iranian Microcontinent (CEIM; for example, Stöcklin, 1974; Stampfli and Borel, 2002; Fürsich et al., 2005; Fürsich et al., 2009; Wilmsen et al., 2009a, b). The results of our study can be correlated with palaeotectonic maps of the Triassic period of the world (Golonka, 2004).

\section{SOURCE AREA WEATHERING}

Factors such as source rock composition, duration of alteration, climatic and tectonic conditions affect the chemical alteration of the source rock (Moosavirad et al., 2011). The mineralogy and chemical composition of terrigenous sediments are controlled be many factors including source area composition and may be affected by alteration in the source area and by the tectonic setting (Bauluz et al., 2000).

Geochemical indices using the major element composition of silicilastic deposits is furthermore used to infer weathering and consequently palaeoclimate conditions. Among the most commonly employed indices are the Chemical Index of Alteration (CIA) after Nesbitt and Young (1982) and the Plagioclase Index of Alteration (PIA) after Fedo et al. (1995).

The Chemical Index of Alteration (CIA) may be obtained by the following equation. 


$$
\mathrm{CIA}=\left[\mathrm{Al}_{2} \mathrm{O}_{3} /\left(\mathrm{AL}_{2} \mathrm{O}_{3}+\mathrm{CaO}+\mathrm{Na}_{2} \mathrm{O}+\mathrm{K}_{2} \mathrm{O}\right)\right] \times 100
$$

Nesbitt and Young $(1982,1984,1989)$ suggested a CIA value of nearly 100 for kaolinite and chlorite, and $70-75$ for average shale. For example, for fresh granite the CIA value is around 50 (Visser and Young, 1990). High values indicate intense chemical weathering in the source area while low rates (i.e., 50 or less) indicate unweathered source areas. The Chemical Index of Alteration values for the shale from the Qadir Member vary from 74.02 to 80.54 with an average of 78.04 (Table 1), indicating moderate to high chemical alteration in the source area. During the Triassic, the Iranian plate was probably located at $25-30^{\circ} \mathrm{N}$. In this palaeo-subtropical succession, a semi-humid climate prevailed during the deposition of these shales. The alteration process, in a A-CN-K diagram, may be obtained by the alteration profile method and also by thermodynamic estimations (Nesbitt and Young, 1984). In this diagram, the initial stages of alteration form a parallel with the A-CN side because sodium and potassium ions are removed by destroying feldspars (plagioclase) in the initial stages of alteration; with the continuation of K-feldspar alteration, potassium ions decrease and the alteration process is shifted to the $\mathrm{Al}_{2} \mathrm{O}_{3}$ composition (Paikaray et al., 2008). However, all shale samples plot near the $\mathrm{Al}_{2} \mathrm{O}_{3}-\mathrm{K}_{2} \mathrm{O}$ join, indicating a high rate of alteration in the source area (Fig. 13B).

The Plagioclase Index of Alteration (PIA; Fedo et al., 1995) was calculated based on the following equation:

$$
\mathrm{PIA}=\left(\mathrm{AL}_{2} \mathrm{O}_{3}-\mathrm{K}_{2} \mathrm{O}\right) /\left(\mathrm{Al}_{2} \mathrm{O}_{3}-\mathrm{K}_{2} \mathrm{O}\right)+\mathrm{CaO}+\mathrm{K}_{2} \mathrm{O} \times 100
$$

The PIA value for the shales in the Qadir Member varies between 84.31 to 91.85 with an average of 78.81 (Table 1). These high values indicate high plagioclase alteration in the source area (Alvarez and Roser, 2007; Ogala et al., 2014). On the Fedo et al. (1995) diagram, samples are mostly located on the right or in the middle of the diagram and the plagioclase composition encompasses albite, oligoclase and andesine (Fig. 13C), which have turned into clay minerals such as illite and chlorite during the chemical alteration.

Also, the relation between alteration and the source rock composition can be evaluated based on the index of compositional variability (ICV) and CIA (Cox et al., 1995; Potter et al., 2005). These indices can be used for identification of types of source rock (Valiani and Rezaee, 2014). The equation is the following:

$$
\mathrm{ICV}=\left(\mathrm{Fe}_{2} \mathrm{O}_{3}+\mathrm{K}_{2} \mathrm{O}+\mathrm{Na}_{2} \mathrm{O}+\mathrm{CaO}+\mathrm{MgO}+\mathrm{TiO}_{2}\right) / \mathrm{Al}_{2} \mathrm{O}_{3}
$$

The ICV index indicates the degree of maturity of fine aluminosilicatic materials delivered to the depositional basin. An ICV of $>1$ indicates immature shales with a high percentage of silicate minerals (without clay minerals), while, more mature clayey rocks with abundant clay minerals proper have lower ICV values (Cox et al., 1995; Moosavirad et al., 2011). The average ICV value obtained for shale of the Qadir member is 0.77 , which shows all these shales are mature rocks associated with abundant clay minerals such as chlorite and illite. Considering the ICV vs. CIA diagrams (Lee, 2002) suggests that the shale of Qadir Member, with this rate of alteration, has originated from intermediate igneous rocks (Fig. 13D).

\section{PALAEOGEOGRAPHY}

From the Precambrian to the Permian, Central Iran was part of northwestern Gondwana (Alavi 1991; Stampfli et al., 1991; Stampfli and Borel, 2002). The Iranian Plate is made up of Central-East Iranian Microcontinent (CEIM), northwestern Mountains and Alborz. It separated from the northeastern margin of Gondwana during the Early Permian (Stampfli and Borel, 2002; Wilmsen et al., 2009a). It led to the closure of Paleotethys by moving northwards during the Triassic and collided with Laurasia and Turan plates (Berberian and King, 1981; Davoudzadeh and Schmit, 1983; Stampfli and Borel, 2002), although the precise age of collision is still under discussion (Şengör et al., 1988; Alavi et al., 1997; Seyed-Emami, 2003; Golonka, 2004). The sedimentary cycle of the Late Triassic to the Middle Jurassic happened between two tectonic events: Early Cimmerian and Middle Cimmerian (Fürsich et al., 2009).

Extensional tectonics is documented in Central and East-Central Iran during the Late Triassic to Late Jurassic following the Early Cimmerian tectonic event and Late Triassic Neotethyan subduction (Fürsich et al., 2003; Fürsich et al., 2005a; Seyed-Emami et al., 2004; Wilmsen et al., 2010; Sheikholeslami, 2016). During the Norian (Nayband Formation as the first formation in the Shemshak Group of Central Iran), there were coastal and marine conditions with the accumulation of 1000 m of strata, while in the Rhaetian, the Qadir Member was deposited in transitional-marine conditions (Shahrabi, 1999). During the Late Triassic (Norian-Rhaetian) there was the beginning of subduction of the Neotethys oceanic crust beneath the Iran Plate at the southern margin of Iran Plate; this event reduced compression of the Iran Plate with subsequent formation (Nayband Basin) of the extensional basins and transgression of the sea onto the Iran Plate (Wilmsen et al., 2009b; Fürsich et al., 2005). In that period, Iran was located between latitude 25-30 North (Fig. 14A; Barrier and Vrielynck, 2008). This supports our interpreting of a semi-humid climate as discussed above. Also, the onset of Neotethys oceanic crust subduction at the southwestern margin of the Iran Plate in Norian-Rhaetian times is well established (Arvin et al., 2007; Sheikholeslami, 2016), in agreement with the active continental margin setting for the shale of the Qadir Member suggested by the Roser and Korsch (1988) diagrams. Neotethys subduction under the Iran Plate and also collision of Iran with Eurasia and the Turan Plate at the end of Triassic Period is consistent with this inferred history (Fig. 14); possibly, shallow angle of Neotethys subduction beneath SW Iran (Ghasemi and Talbot, 2006) caused the limited volcanic activity in the extensional basin (such as the Tabas Block in CEIM).

\section{CONCLUSIONS}

Shales of the Qadir Member in the Nayband Formation in East Central Iran are composed of quartz, illite and chlorite. Analyses of the data obtained from geochemical investigations indicates that the source rocks of siliciclastic deposits in the Qadir Member are intermediate igneous rocks. In different chemical weathering indices such as the CIA and PIA, and in a A-CN-K ternary diagram, all shale samples of the Qadir Member plot parallel to the A-K line, indicating moderate to high chemical weathering in the source region. The geochemical re- 


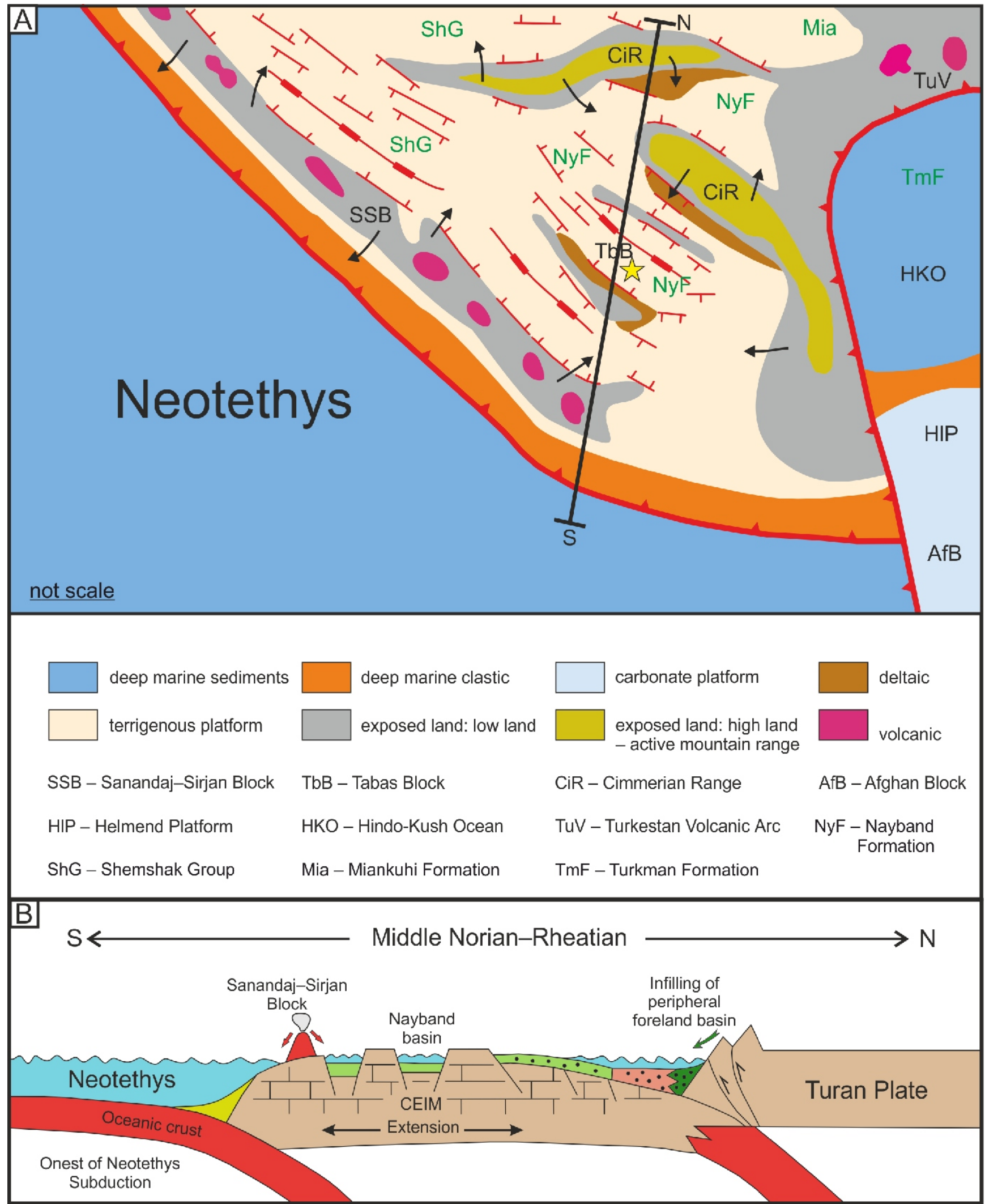

Fig. 14A - palaeogeographic sketches; B - geodynamic models of the Late Triassic (Middle Norian-Rheatian) for the Early Cimmerian Orogeny on the Iran Plate (modified after Barrier and Vrielynck 2008; Wilmsen et al., 2009b)

CEIM - Central-East Iranian Microcontinent; the study area is indicated by a yellow asterisk on A 
sults also suggest the tectonic setting of an active continental margin for these deposits, which corresponds to the Early Cimmerian tectonic event, Neothetys subduction beneath the Iran Plate, and collision of the Iran Plate with the Turan Plate.

Acknowledgements. This research is part of the senior author's M.Sc. thesis and was supported by the Department of
Geology, Ferdowsi University of Mashhad (research code: 3/38412), Iran. The authors gratefully thank Tabas Parvadeh Coal Company (TPCCO) for providing facilities during field studies. We would like to acknowledge Dr. T. Bajda, editor of the Geological Quarterly, and the two anonymous reviewers, for their review and suggestions that significantly improved our manuscript.

\section{REFERENCES}

Aghanabati, A., 2006. Geology of Iran (in Persian). Geological Survey of Iran, Tehran.

Akarish, A.I., El-Gohary, A.M., 2008. Petrography and geochemistry of lower Paleozoic sandstones, East Sinai, Egypt: implications for provenance and tectonic setting. Journal of African Earth Sciences, 52: 43-54.

Alavi, M., 1991. Sedimentary and structural characteristics of the Paleo-Tethys remnants in Northeastern Iran. Geological Society of America Bulletin, 103: 983-992.

Alavi, M., Vaziri, H., Seyed-Emami, K., Lasemi, Y., 1997. The Triassic and associated rocks of the Nakhlak and Aghdarband areas in central and northeastern Iran as remnants of the southern Turanian active continental margin. Geological Society of America Bulletin, 109: 1563-1575.

Alvarez, N.C., Roser, B.P., 2007. Geochemistry of black shales from the Lower Cretaceous Paja Formation, Eastern Cordillera, Colombia: source weathering, provenance and tectonic setting. Journal of South American Earth Sciences, 23: 271-289.

Armas, P., Moreno, C., Sánchez, M. L., González, F., 2014. Sedimentary palaeoenvironment, petrography, provenance and diagenetic inference of the Anacleto Formation in the Neuquén Basin,Late Cretaceous, Argentina. Journal of South American Earth Sciences, 53: 59-76.

Arvin, M., Pan, Y., DarGahi, S., MalekiZadeh, A., Babaei, A., 2007. Petrochemistry of the Siah-Kuh granitoid stock southwest of Kerman, Iran: implications for initiation of Neotethys subduction. Journal of Asian Earth Sciences, 30: 474-489.

Barrier, E., Vrielynck, B., 2008. Palaeotectonic maps of the Middle East - tectono-sedimentary-palinsspastic maps from the Late Norian to Pliocene. Paris (Commission for the Geological Map of the World; CGMW/CCGM).

Bauluz, B., Mayayo, M.J., Fernandez-Nieto, C., Lopez, J.M.G., 2000. Geochemistry of Precambrian and Paleozoic siliciclastic rocks from the Iberian Range (NE Spain): implications for source-area weathering, sorting, provenance, and tectonic setting. Chemical Geology, 168: 135-150.

Bayet-Goll, A., Hosseini Barzi, M., 2011. Geochemistry of major elements of siliciclastic deposits from Shirgesht Formation, in Kalmard block, Central Iran, implications for provenance, tectonic setting, and weathering intensity. Journal of Scientific Quarterly Geosciences, 20: 101-112.

Berberian, M., King, G.C.P., 1981. Towards a paleogeography and tectonic evolution of Iran. Canadian Journal of Earth Sciences, 18: $210-265$.

Bhatia, M.R., 1983. Plate tectonics and geochemical composition of sandstones. The Journal of Geology, 91: 611-627.

Bhatia, M.R., Crook, K.A., 1986. Trace element characteristics of graywackes and tectonic setting discrimination of sedimentary basins. Contributions to Mineralogy and Petrology, 92: 181-193.

Cox, R., Lowe, D.R., Cullers, R.L., 1995. The influence of sediment recycling and basement composition on evolution of mudrock chemistry in the southwestern United States. Geochimica et Cosmochimica Acta, 59: 2919-2940.

Crook, K.A.W., 1974. Lithogenesis and geotectonics: the signature of compositional variation on flysch arenites (graywackes) in modern and ancient geosynclinal sedimentation. SEPM Special Publication, 19: 304-310.

Cullers, R.L., 2000. The geochemistry of shales, siltstones and sandstones of Pennsylvanian-Permian age, Colorado, USA: implications for provenance and metamorphic studies. Lithos, 51: 181-203.

DaPeng, L., YueLong, C., Zhong, W., Yu, L., Jian, Z., 2012. Paleozoic sedimentary record of the Xing-Meng Orogenic Belt, Inner Mongolia: Implications for the provenances and tectonic evolution of the Central Asian Orogenic Belt. Chinese Science Bulletin, 57: 776-785.

Das, B.K., Al-Mikhlafi, A.S., Kaur, P., 2006. Geochemistry of Mansar Lake sediments, Jammu, India: implication for source-area weathering, provenance, and tectonic setting. Journal of Asian Earth Sciences, 26: 649-668.

Davoudzadeh, M., Schmit, K., 1983. A review of Mesozoic paleogeography and tectonic evolution of Iran. Tehran: Geological Survey of Iran, 51: 415-435.

Dickinson, W.R., 1985. Interpreting Provenance Relations from Detrital Modes of Sandstones. In: Provenance of Arenites (ed. G.G. Zuffa): 333-363. Springer, Dordrecht (Reidel Publishing Company).

Dickinson, W.R., Suczek, C.A., 1979. Plate tectonics and sandstone compositions. AAPG Bulletin, 63: 2164-2182.

Fedo, C.M., Nesbitt, H.W., Young, G.M., 1995. Unraveling the effects of potassium metasomatism in sedimentary rocks and paleosols, with implications for paleoweathering conditions and provenance. Geology, 23: 921-924.

Fleming, E., Flowerdew, M.J., Smyth, H.R., Scott, R.A., Morton, A.C., Omma, J.E., Frei, D., Whitehouse, M.J., 2016. Provenance of Triassic sandstones on the southwest Barents Shelf and the implication for sediment dispersal patterns in northwest Pangaea. Marine and Petroleum Geology, 78: 516-535.

Floyd, P.A., Leveridge, B.E., 1987. Tectonic environment of the Devonian Gramscatho basin, South Cornwall: framework mode and geochemical evidence from turbiditic sandstones. Journal of Geological Society, 144: 531-542.

Fürsich, F.T., Wilmsen, M., Seyed-Emami, K., Majidifard, M.R., 2003. Evidence of synsedimentary tectonics in the northern Tabas Block, east-central Iran: the Callovian (Middle Jurassic) Sikhor Formation. Facies, 48: 151-170.

Fürsich, F.T., Hautmann, M., Senowbari-Daryan, B., Seyed-Emami, K., 2005. The Upper Triassic Nayband and Darkuh Formations of east-central Iran: Stratigraphy, facies patterns and biota of extensional basins on an accreted terrane. Beringeria, 35: 53-133.

Fürsich, F.T., Wilmsen, M., Seyed-Emami, K., Majidifard, M.R., 2009. Lithostratigraphy of the Upper Triassic-Middle Jurassic 
Shemshak Group of Northern Iran. Geological Society of London, Special Publications, 312: 129-160.

Garver, J.I., Royce, P.R., Smick, T.A., 1996. Chromium and nickel in shale of the Taconic foreland: a case study for the provenance of fine-grained sediments with an ultramafic source. Journal of Sedimentary Research, 100: 100-106.

Getaneh, W., 2002. Geochemistry provenance and depositional tectonic setting of the Adigrat Sandstone northern Ethiopia. Journal of African Earth Sciences, 35: 185-198.

Ghasemi, A., Talbot, C.J., 2006. A new tectonic scenario for the Sanandaj-Sirjan Zone (Iran). Journal of Asian Earth Sciences, 26: 683-693.

Golonka, J., 2004. Plate tectonic evolution of the southern margin of Eurasia in the Mesozoic and Cenozoic. Tectonophysics, $\mathbf{3 8 1}$ 235-273.

Hayashi, K.I., Fujisawa, H., Holland, H.D., Ohmoto, H., 1997. Geochemistry of $\sim 1.9 \mathrm{Ga}$ sedimentary rocks from northeastern Labrador, Canada. Geochimica et Cosmochimica Acta, 61: 4115-4137.

Hessler, A.M., Lower, D.M., 2006. Wethering and sediment generation in the Archean: an integrated study of the evolution of siliciclastic sedimentary rocks of the $3.2 \mathrm{Ga}$ Moodies Group Barberton Greenstone Belt, South Africa. Precambrian Research, 151: 185-210.

Humphreys, B., Morton, A.C., Hallsworth, C.R., Gatliff, W.R. Riding, J., 1995. An integrated approach to provenance studies: a case example from the Upper Jurassic of the Central Graben, North Sea. In: Developments in Sedimentary Provenance Studies (eds. A.C. Morton, S.P. Todd and P.D.W Haughton): $230-251$. Published by the Geological Society of London.

Jafarzadeh, M., Moussavi-Harami, R., Amini, A., Mahboubi, A., Farzaneh, F., 2014. Geochemical constraints on the provenance of Oligocene- Miocene siliciclast deposits (Zivah Formation) of NW Iran: implications for the tectonic evolution of the Caucasus. Arabian Journal of Geosciences, 7: 4245-2463.

Jin, Z., Li, F., Cao, J., Wang, S., Yu, J., 2006. Geochemistry of Daihai Lake sediments, Inner Mongolia, north China: implications for provenance, sedimentary sorting, and catchment weathering. Geomorphology, 80: 147-163.

Khanehbad, M., Moussavi-Harami, R., Mahboubi, A., Nadjafi, M. Mahmudy Gharaie, M.H., 2012a. Geochemistry of Carboniferous Sandstones (Sardar Formation), East-Central Iran: implication for Provenance and Tectonic Setting. Acta Geologica Sinica (English Edition), 86: 1200-1210.

Khanehbad, M., Moussavi-Harami, R., Mahboubi, A., Nadjafi, M. 2012b. Geochemistry of Carboniferous Shales of the Sardar Formation, East Central Iran: implication for Provenance, Paleoclimate and Paleo Oxygenation Conditions at a Passive Continental Margin. Geochemistry International, 50: 777-790.

Lee, Y.I., 2002. Provenance derived from the geochemistry of late Paleozoic-early Mesozoic mudrocks of the Pyeongan Supergroup, Korea. Sedimentary Geology, 149: 219-235.

Mahavaraju, J., 2015. Geochemistry of Late Cretaceous sedimentary rocks of the Cauvery Basin, South India: constraints on paleo weathering, provenance, and end Cretaceous environments. Chemostratigraphy, 8: 185-214.

Malekzadeh Shafaroudi, A., Karimpour, M.H., Stern, C.R., 2015 The Khopik porphyry copper prospect, Lut Block, Eastern Iran geology, alteration and mineralization, fluid inclusion, and oxygen isotope studies. Ore Geology Reviews, 65: 522-544.

Moosavirad, A.M., Janardhana, M.R., Sethumadhav, M.S., Moghadam, M.R., Shankara, M., 2011. Geochemistry of lower Jurassic shales of the Shemshak Formation, Kerman Province, Central Iran: provenance, source weathering and tectonic setting. Chemie der Erde-Geochemistry, 71: 279-288.

Moussavi-Harami, R., Ghaemi, F., 2006. Korit Geological Map 1:100,000. Geological Survey and Mineral Exploration of Iran Tehran.
Nesbitt, H.W., Young, G.M., 1982. Early Proterozoic climates and plate motions inferred from major element chemistry of lutites. Nature, 299: 715-717.

Nesbitt, H.W., Young, G.M., 1984. Prediction of some weathering trends of plutonic and volcanic rocks based upon thermodynamic and kinetic consideration. Geochimcal Cosmochimcal Acta, 48: 1523-1534.

Nesbitt, H.W., Young, G.M., 1989. Formation and diagenesis of weathering profile. The Journal of Geology, 97: 129-147.

Ogala, J.E., Olobaniyi, S.B., Omo-Irabor, O.O., Adaikpoh, E.O. 2014. Petrographic and geochemical study of the Maastrichtian Ajali Sandstone, North Central Nigeria. Geological Quarterly, 59 (1): 79-90

Osman, M., 1996. Recent to Quaternary River Nile sediments: a sedimentological characterization on samples from As428. M.J.J. Rahman and S. Suzuki wan to Naga-Hammadi, Egypt. Unpubl. Ph.D. thesis, University of Vienna, Vienna.

Paikaray, S., Banerjee, S., Mukherji, S., 2008. Geochemistry of shales from the Paleoproterozoic to Neoproterozoic Vindhyan Supergroup: Implications on provenance, tectonics and paleoweathering. Journal of Asian Earth Sciences, 32: 34-48.

Pettijohn, F.J., Potter, P.E., Siever, R., 1987. Sand and Sandstone (2nd). Springer-Verlag, New York.

Potter, P.E., Maynard, J.B., Depetris, P.J., 2005. Mud and Mudstone: Introduction and Overview. Springer-Verlag, Berlin Heidelberg.

Rieser, A.B., Neubauer, F., Liu, Y., Ge, X., 2005. Sandstone provenance of north-western sectors of the intracontinental Cenozoic Qaidam basin, western China: tectonic vs. climatic control. Sedimentary Geology, 177: 1-18.

Roser, B.P., Korsch, R.J., 1986. Determination of tectonic setting of sandstone-mudstone suites using $\mathrm{SiO}_{2}$ content and $\mathrm{K}_{2} \mathrm{O} / \mathrm{Na}_{2} \mathrm{O}$ ratio. Journal of Geology, 94: 635-650.

Roser, B.P., Korsch, R.J., 1988. Provenance signatures of sandstone-mudstone suites determined using discriminant function analysis of major-element data. Chemical Geology, 67: 119-139.

Sabbagh Bajestani, M., Mahboubi, A., Moussavi-Harami, R., Nadjafi, M., 2018. Petrography and geochemistry of sandstones succession of the Qal'eh Dokhtar Formation (Middle-Upper Jurassic), East Central Iran: implications for provenance, tectonic setting and palaeoweathering. Journal of African Earth Sciences, 147: 523-535.

Saidi, M., Masoudi, M., Nazemi, M., Faridi, M., NaimiGhassabian, N., 2006. Gharb-E-Shekasteh Abshaleh Geological Map 1:100,000. Geological Survey and Mineral Exploration of Iran, Tehran.

Salehi, M.A., Moussavi-Harami, S.R., Mahboubi, A., Wilmsen, M., Heubeck, C., 2014. Tectonic and palaeogeographic implications of compositional variations within the siliciclastic Ab-Haji Formation (Lower Jurassic, east-central Iran). Neues Jahrbuch für Geologie und Paläontologie-Abhandlungen, 271: 21-48.

Salehi, M.A., Mazroei Sebdani, Z., Pakzad, H.R., Bahrami, A., Fürsich, F.T., Heubeck, C., 2018. Provenance and palaeogeography of uppermost Triassic and Lower Cretaceous terrigenous rocks of central Iran: Reflection of the Cimmerian events. Neues Jahrbuch für Geologie und PaläontologieAbhandlungen, 288: 49-77.

Schieber, J., 1992. A combined petrographical-geochemical provenance study of the Newland Formation, Mid-Proterozoic of Montana. Geological Magazine, 129: 223-237.

Şengör, A.M.C., Altiner, D., Cin, A., Ustaömer, T., Hsü, K.J., 1988. Origin and assembly of the Tethyside orogenic collage at the expense of Gondwana Land. Geological Society of London, Special Publications, 37: 119-181.

Seyed-Emami, K., 2003. Triassic in Iran. Facies, 48: 91-106.

Seyed-Emami, K., Fürsich, F.T., Wilmsen, M., 2004. Documentation and significance of tectonic events in the northern Tabas Block (East-Central Iran) during the Middle and Late Jurassic. Rivista Italiana di Paleontologia e Stratigrafia, 110: 163-171. 
Shahrabi, M., 1999. Triassic in Iran (in Persian). Geological Survey of Iran, Tehran.

Sheikholeslami, M.R., 2016. Tectono-stratigraphic evidence for the opening and closure of the Neotethys Ocean in the southern Sanandaj-Sirjan zone, Iran. Geological Society of America Special, SPE525-09.

Stampfli, G.M., Marcoux, J., Baud, A., 1991. Tethyan margins in space and time. Palaeogeography, Palaeoclimatology, Palaeoecology, 87: 373-409.

Stampfli, G.M., Borel, G.D., 2002. A plate tectonic model for the Paleozoic and Mesozoic constrained by dynamic plate boundaries and restored synthetic oceanic isochrones. Earth and Planetary Science Letters, 196: 17-33.

Stöcklin J., 1974. Possible Ancient Continental Margins in Iran. In: Geology of Continental Margins (eds. C.A. Burk and C.L. Drake). Springer, Berlin, Heidelberg.

Taylor, S.R., McLennan, S.M., 1985. The continental crust: its composition and evolution. Blackwell Scientific Publications, Oxford.

Valiani, Z., Rezaee, P., 2014. Chemical Characteristics, Provenance Determination and Genesis Conditions of Clay Deposits of Kahrizak Formation (Early-Late Pleistocene), East of Tehran, Iran. GSTF Journal of Geological Sciences (JGS), 1: 15-22.

Verma, S.P., Armstrong-Altrin, J.S., 2013. New multi-dimensional diagrams for tectonic discrimination of siliciclastic sediments and their application to Precambrian basins. Chemical Geology, 355: 117-133.

Visser, J.N.J., Young, G.M., 1990. Major element geochemistry and palaeoclimatogy of the Permo-Carboniferous glacigene Dwyka Formation and post-glacial mudrocks in southern Africa Palaeogeography, Palaeoclimatology, Palaeoecology, 81: 49-57.
Weltje, G.J., 2002. Quantitative analysis of detrital modes: statistically rigorous confidence regions in ternary diagrams and their use in sedimentary petrology. Earth-Science Reviews, 57: 211-253.

Weltje, G.J., von Eynatten, H., 2004. Quantitative provenance analysis of sediments: review and outlook. Sedimentary Geology, 171: 1-11.

Wilmsen, M., Fürsich, F.T., Seyed-Emami, K., Majidifard, M.R., 2009a. An overview of the stratigraphy and facies development of the Jurassic System on the Tabas Block, east-central Iran. Geological Society of London, Special Publications, 312: 323-343.

Wilmsen, M., Fürsich, F.T., Seyed-Emami, K., Majidifard, M.R., Taheri, J., 2009b. The Cimmerian Orogeny in northern Iran: tectono-stratigraphic evidence from the foreland. Terra Nova, 21: 211-218.

Wilmsen, M., Fürsich, F.T., Seyed-Emami, K., Majidifard, M.R., Zamani-Pedram, M., 2010. Facies analysis of a large-scale Jurassic shelf-lagoon: the Kamar-e-Mehdi Formation of east-central Iran. Facies, 56: 59.

Wronkiewicz, D.J., Condie, C., 1987. Geochemistry of Archean Shales from the Witwatersrand Supergroup, South Africa: Source- Area Weathering and Provenance. Geochim et cosmochimica Acta, 51: 2401-2416.

Yong, I.L., 2009. Geochemistry of shales of the Upper Cretaceous Hayang Group, SE Korea: implications for provenance and source weathering at an active continental margin. Sedimentary Geology, 215: 1-12.

Zaid, S.M., 2015. Geochemistry of sandstones from the Pliocene Gabir Formation, north Marsa Alam, Red Sea, Egypt: implication for provenance, weathering and tectonic setting. Journal of African Earth Sciences, 102: 1-17. 